\title{
State Challenges to the Patient Protection and AfFordable Care ACT: The CASE FOR A NeW FEDERALIST JURISPRUDENCE
}

\author{
Christopher B. Serak ${ }^{*}$
}

I. INTRODUCTION

II. BACKGROUND-LEGAL CHANGES AND STATE CHALLENGES

A. Legal Changes in the Patient Protection and Affordable Care

Act.

B. State Challenges to the Patient Protection and Affordable

Care Act..

III. THE CURRENT STATE OF FEDERALIST JURISPRUDENCE .......................334

A. The Anti-Commandeering Rule .............................................335

B. Other Important Concepts to Federalist Jurisprudence...........337

IV. A NEW APPROACH FOR FEDERALIST JURISPRUDENCE .........................342

A. Values of Federalism ................................................................343

B. An 'Expressive' Application of the Anti-Commandeering

Rule.

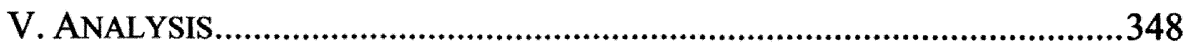

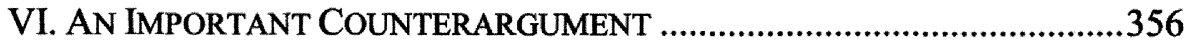

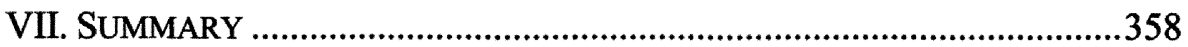

\section{INTRODUCTION}

The state-initiated challenges to the Patient Protection and Affordable Care Act (the "Act") give the courts an important opportunity to recognize state autonomy as an essential aspect of constitutional governance. ${ }^{2}$ Existing federalist jurisprudence does not adequately protect the sovereign ca-

* J.D. Candidate, 2012, Indiana University Robert H. McKinney School of Law; M.P.A., 2012, Indiana University School of Public and Environmental Affairs-Indianapolis; B.S. Political Science, 2008, Wabash College. (2010).

1. Patient Protection and Affordable Care Act, Pub. L. No. 111-148, 124 Stat. 119

2. See Virginia ex rel. Cuccinelli v. Sebelius, 728 F. Supp. 2d 768, 772 (E.D. Va. Dec. 13, 2010), vacated, 656 F.3d 253 (4th Cir. 2011), petition for cert. filed, No. 11-420 (U.S. filed Sept. 30, 2011) (addressing Congress's power to require the purchase of health insurance under the Commerce Clause); Florida ex rel. Bondi v. United States Dep't of Health \& Human Servs., 780 F. Supp. 2d 1256 (N.D. Fla. 2011), aff'd in part, rev'd in part sub nom., Florida ex rel. Att'y. Gen. v. United States Dep't of Health \& Human Servs., 648 F.3d 1235 (11th Cir. 2011), cert. granted, 132 S. Ct. 604 (2011) (determining the individual mandate question, as well as claims against two provisions under the anti-commandeering rule). 
pacity of the states to act as legitimate sources of public policy. ${ }^{3}$ In particular, the anti-commandeering rule fails to protect the state's regulatory infrastructure from federal encroachment. ${ }^{4}$ As a result, there are aspects of the Act that appear on their face to violate basic premises of federalism that are unlikely to be remedied by the courts. ${ }^{5}$ For example, the Act establishes a broad regulatory scheme and requires the states to assume administrative responsibility for the bureaucratic aspects. At the same time, the Act transfers regulatory power over health insurance to the federal government, an area traditionally reserved to the states. ${ }^{6}$ Judicial compliance with this scheme can be corrected by applying a judicial rule that takes an "expressive" approach to defining the limits of state and federal power.

An expressive theory of law looks at the social meaning behind government action. ${ }^{7}$ It examines how government action communicates values of governance, and how this affects perceptions of the values that underlie the rule of law. Current jurisprudence looks for syntactical limits on federal enumerated powers, such as the "economic activity" threshold of the Commerce Clause. 8 This approach reads each structural provision in isolation, effectively defining each clause as self-limiting rather than in symbiotic balance with the remaining document. The problem with this approach is that while deliberately designing a system of vertically divided power with

3. See, e.g., Adam B. Cox, Expressivism in Federalism: A New Defense of the AntiCommandeering Rule?, 33 LoY. L.A. L. REV. 1309 (2000) (arguing for an expressive approach to federalist jurisprudence); see also, e.g., Printz v. U.S., 521 U.S. 898 (1997) (applying the anti-commandeering rule in a manner that does not adequately protect state regulatory autonomy from Congressional exercises of its plenary powers).

4. See Cox, supra note 3, at 1314 (arguing that the anti-commandeering rule fails to protect state regulatory autonomy); see also New York v. United States, 505 U.S. 144, 161 (1992) (citing Hodel v. Virginia Surface Mining \& Reclamation Assn., Inc., 452 U.S. 264, 307 (1981)) (explaining the purpose of the anti-commandeering rule is to protect the states where federal law "commandee[rs] the legislative processes of the States by directly compelling them to enact and enforce a federal regulatory program").

5. Order and Memorandum Opinion on Defendant's Motion to Dismiss, Florida ex rel. McCollum v. United States Dep't of Health \& Human Servs., 716 F. Supp. 2d 1120, 1155 (N.D. Fla. 2010) (granting the defendant's motion to dismiss the anti-commandeering claims relating to states' establishment of American Health Benefit Exchanges).

6. Hal S. Scott, Federalism and Financial Regulation, in FEDERAL PREEMPTION: STATES' POWERS, NATIONAL INTERESTS, 139, 153 (Richard Epstein \& Michael S. Greve eds., 2007) (explaining that the McCarran-Ferguson Act gave states autonomy over insurance regulation) (quoting the statute) ("The business of insurance ... shall be subject to the laws of the several states," and "[n]o Act of Congress shall be construed to invalidate, impair, or supersede any law enacted by any State for the purpose of regulating the business of insurance.") 15 U.S.C. § 1012(a)-(b) (2011)).

7. See Cox, supra note 3, at 1316 (explaining how government actions are perceived by the public as social messages regarding political truth and the relative power of the government actor). In this Note expressivism will be applied in terms of the political values enforced by structural provisions of the Constitution, and how these values should be used as a threshold on state and federal power.

8. See, e.g., United States v. Lopez, 514 U.S. 549, 561-562 (1995), and United States v. Morrison, 529 U.S. 598, 610-611 (2000) (analyzing the 'economic' nature of the regulated activity to determine if it falls within Congress's power under the Commerce Clause). 
expressly limited federal authority, the text of the U.S. Constitution says little regarding the regulatory autonomy of the states. ${ }^{9}$ In fact, without an understanding of the social and political values underlying divided sovereignty, and without looking at the constitution's text as a symbiotic whole, the powers enumerated to Congress by Article 1, Section 8 of the Constitution, "fairly admit of a construction that permits the national government to act very nearly as it were a government of general legislative power."10 Thus, where the courts view textual provisions regarding state and federal power as solely self-limiting, the states are left largely at the whim of federal authority.

Modern jurisprudence reflects this concept of broad national power. In fact, the expansion of federal power under the Commerce Clause led Justice Rehnquist to refer to the $10^{\text {th }}$ Amendment's reservation of broad police powers to the states as "one of the greatest fictions of our federal system."11 While a strong federal government is essential, and it was this need for a general government "adequate to the exigencies of government and the preservation of the union" that led to the adoption of the U.S. Constitution, federalist jurisprudence must also protect the role of the states. ${ }^{12}$ For this reason, it is necessary to couple the legal theory underlying the anticommandeering rule with an expressive understanding of the constitutional limits of state and federal power.

It is the purpose of this Note to outline a new judicial approach to the limits of state and federal power that expresses the values that underlie the structural provisions of the Constitution. Such a rule flows from the idea that "the nature of a constitutional system imposes on the judiciary an obligation to engage in principled, consistent analysis and to make decisions that are capable of rational reconciliation with governing textual directives." ${ }^{\prime 3}$ This rule will be adapted from the anti-commandeering rule. It

9. See, e.g., Michael Paulsen, Debate on the Original Meaning of the Commerce, Spending and Necessary and Proper Clauses, in ORIGINALISM: A QUARTER CENTURY OF DEBATE, 253 (Steven G. Calabresi ed., 2007) (arguing that a textual reading of the Constitution does not explicitly protect "federalism" as a requisite structural aspect of political order).

10. Id. at 254 (arguing that the power to tax, spend, regulate commerce, wage war and displace state regulation expressly enumerated to Congress by Article 1, Section 8 of the Constitution necessarily suggests broad national powers).

11. Hodel v. Virginia Surface Mining \& Reclamation Assn., Inc., 452 U.S. 264, 307 (1981) (Rehnquist, J., concurring).

12. THE FEDERALIST No. 40 (James Madison) (arguing that the need for a stronger federal government was the underlying reason for the disposal of the Articles of Confederation and ratification of the federalist Constitution and explaining further that the states remained in their sovereign capacity, limited only by the powers specifically enumerated to Congress).

13. Martin H. Redish, The Constitution as Political Structure, 9-10 (Oxford University Press 1995); see also Charlton C. Copeland, Federal Law in State Court: Judicial Federalism Through a Relational Lens, 19 WM. \& MARY BILL RTS. J. 511, 512 (2011) (explaining that "[r]elational federalism enforcement is grounded in the recognition that the 
will examine state and federal action for how it impacts the government's ability to realize the values that underlie the federal system designed by the U.S. Constitution. It will in turn be applied to the provisions of the Patient Protection and Affordable Care Act to demonstrate its prima facie violations of these values. Federal regulation of health insurance as a general matter is not the issue of this critique. Federal reform of health insurance can be done constitutionally and may be an appropriate way to approach existing problems. Rather, this Note will demonstrate why the particular tact of the Act's regulatory scheme, the use of state governments as administrative bodies, does not fit within the political structure laid out in the Constitution. If nothing else, this Note will bring to light how existing Supreme Court jurisprudence ignores fundamental mandates in the constitution's structuring of political power, in favor of judging Congressional action through a tailored, self-contained reading of Article 1, Section 8. The expressive approach advocated here is just one way to correct this discrepancy, and the state challenges to the Patient Protection and Affordable Care Act are only one embodiment of this jurisprudential failure.

Before the recommended rule can be developed and applied to the Act, it is necessary to examine the provisions of the Act and the stateinitiated claims to enjoin their enforcement. It is also essential to review current understandings of state and federal power, and the inadequacy of the anti-commandeering rule to protect state autonomy in this jurisprudential context. Next, it is necessary to outline the values that manifest from a well-enforced federalist system. This section will explore the purposes behind the nation's governing architecture in terms of the values it conveys. These values will in turn be used to construct the anti-commandeering rule in a manner that protects state regulatory autonomy and in turn the Constitutional rule of law. ${ }^{14}$ Finally, this rule will be applied to the Patient Protection and Affordable Care Act to show both its benefits to and inherent violations of constitutional federalism.

\section{BACKGROUND-LEGAL CHANGES AND STATE CHALLENGES}

\section{A. Legal Changes in the Patient Protection and Affordable Care Act}

The most controversial provision of the Patient Protection and Affordable Care Act requires that all citizens acquire a qualified health insurance

\footnotetext{
Constitution establishes an enduring relationship between states and the national government," and arguing that government activity should be adjudged for how it complies with "behavioral norms . . . that are consistent with the enduring nature of their interaction [between the national government and the state governments] under the constitutional structure of federalism.").

14. See Cox, supra note 3, at 1348 (arguing that anti-commandeering cases do "not rely explicitly on expressive harms" when invalidating intrusive federal legislation, and therefore fail to protect state autonomy).
} 
policy or pay a fine. ${ }^{15}$ This provision is referred to in the Act as the Essential Coverage Requirement, and informally as "the individual mandate." Congress argues that the individual mandate is within its enumerated power "to regulate commerce with foreign nations, and among the several states, and with the Indian tribes."16 The Commerce Clause, however, has never been interpreted "to include the regulation of a person's decision not to purchase a product, notwithstanding its effect on interstate commerce." However, the district court in the Florida proceedings notes that while this exercise of power may be unprecedented, it is not necessarily unconstitutional. $^{18}$ If the individual mandate is upheld by the Supreme Court, its enforcement will serve to expand the scope of Congress's sovereign authority and retract that of the states. Translated into judicial precedent, this outcome is in itself a change of law. In this way, the enforcement of the individual mandate would result in both a new parameter on individual decision-making and a substantive change in Constitutional law.

The Act also contains important changes for the regulation of health insurance. It introduces federal control through the direct regulation of health insurers, the establishment of a regulatory program for the administration of intrastate insurance markets, and the ubiquitous oversight of the Department of Health and Human Services. Beginning with the specific regulation of health insurers, the Act amends the Public Health Service Act to guarantee all Americans access to health care by requiring insurers to accept all applicants for coverage. ${ }^{19}$ In the same set of amendments, the Act interdicts insurers from denying coverage to individuals based on a preexisting condition or current health status; and also from charging different rates for any reason other than age, the type of plan (individual or group), the rating area, or tobacco use. ${ }^{20}$ Additionally, the Act requires the Secretary of Health and Human Services ("Secretary") to develop an "essential health benefits package" that establishes the minimum set of benefits all health insurance policies must offer. ${ }^{21}$ It should be noted that these changes

15. Patient Protection and Affordable Care Act $\$ 1501,42$ U.S.C. $\$ 18091$ (2010); Florida ex rel. Bondi v. United States Dep't. of Health \& Human Servs., 780 F. Supp. 2d 1256 (N.D. Fla. 2011) (holding $\S 1501$ unconstitutional and the remaining provisions invalid as non-severable), aff'd in part and rev'd in part, 648 F.3d 1235 (4th Cir. 2011) (finding the mandate unconstitutional but reversing finding of non-severability).

16. U.S. ConsT. art. I, $\S 8$, cl. 3 .

17. Virginia ex. rel. Cuccinelli v. Sebelius, 702 F. Supp. 2d 598, 614 (E.D. Va. 2010), vacated, No. 11-1057, 11-1058 (4th Cir. Sept. 8, 2011).

18. Florida ex. rel. McCollum v. United States Dep't. of Health \& Human Servs., 780 F. Supp. 2d 1256, 1277 (N.D. Fla. 2010). (2011).

19. Patient Protection and Affordable Care Act $\S 1201,42$ U.S.C. $\S 300 \mathrm{gg}-1$ (a)

20. Id. Patient Protection and Affordable Care Act $\S 1201,42$ U.S.C.S $\S \S$ 300gg(a)(1), -3(a), -4(a)(1) (2011). (2011).

21. Patient Protection and Affordable Care Act $\$ 1302$ (b), 42 U.S.C. $\S 18022$ (b) 
in the law are again two-fold: they introduce new rules for society, while broadening the jurisprudential concept of federal sovereignty under the Constitution. The direct regulation of minute aspects of insurance law also contradicts the long-standing principle of reverse preemption embodied by the McCarran-Ferguson Act, which protects state regulation of the "business of insurance" from incidental preemption by broad acts of Congress. ${ }^{22}$ However, some courts have held that the reverse preemptive effect of the McCarran-Ferguson Act does not apply where the challenged federal law is a deliberate effort by Congress to regulate the insurance industry. ${ }^{23}$ In turn, the McCarran-Ferguson Act will not likely be used to limit the preemptive effect of the Patient Protection and Affordable Care Act.

As mentioned above, the Patient Protection and Affordable Care Act makes important changes to the administration of intrastate insurance markets. $^{24}$ These changes are most important for the purposes of this Note because they coerce the states to undertake a specific regulatory program in an area traditionally reserved to the police powers of the states. ${ }^{25}$. Since the passage of the McCarran-Ferguson Act in 1945, States have enjoyed statutory authority over the regulation of the intrastate insurance industry. ${ }^{26} \mathrm{Be}$ fore this, state sovereignty over insurance regulation was supported by the 1868 Supreme Court case of Paul v. Virginia ${ }^{27}$ which ruled that issuing an insurance policy is not a commercial transaction, and is therefore reserved to the states' general police power. ${ }^{28}$ The McCarran-Ferguson Act was passed following a circuit court decision overruling Paul and subjecting

22. McCarran-Ferguson Act, 15 U.S.C. $\S 1011$ (2011) (limiting the regulation of insurance to the states); see also, e.g., U.S. Dep't of Treasury v. Fabe, 598 U.S. 491 (1993) (interpreting McCarran-Ferguson's preemptive effect as applicable to federal laws that regulate "the relationship between insurer and insured, the type of policy which [can] be issued, its reliability, interpretation, and enforcement").

23. See, e.g., Pallozi v. Allstate Life Insurance Co., 198 F.3d 28 (1999) (refusing to apply the McCarran-Ferguson Act to invalidate a provision of the Americans with Disabilities Act that limits the underwriting power of insurance companies in regards to policies drafted for individuals with HIV or AIDS).

24. See generally Patient Protection and Affordable Care Act $\S \S 1311-1313,1321$ 1324, 1331-1334, 42 U.S.C. $\S \S 18031-18033,18041-18044,18051-18054$ (2011).

25. See Scott, supra note 6, at 153 (explaining the history of state autonomy over insurance regulation).

26. See generally McCarran-Ferguson Act, 15 U.S.C. $\S 1011$ (2011) (limiting the regulation and taxation of the insurance industry to the states).

27. Paul v. Virginia, 75 U.S. 168 (1868), overruled in part by United States v. SouthEastern Underwriters Ass'n, 322 U.S. 533, 553 (1944) (ruling that insurance companies operate across state lines and are therefore interstate corporations subject to federal anti-trust laws), superseded by statute as stated in United States Dep't of Treasury v. Fabe, 508 U.S. 491, 507 (1993) (noting that the McCarran-Ferguson Act not only overruled South-Eastern Underwriters, but "transformed the legal landscape" regarding pre-emption).

28. Paul v. Virginia, 75 U.S. 168, 183 (1868), overruled in part by United States v. South-Eastern Underwriters Ass'n, 508 U.S. 491 (1944), superseded by statute as stated in United States Dep't of Treasury v. Fabe, 508 U.S. 491 (1993). 
insurers to antitrust laws. ${ }^{29}$ As noted above, some courts have refused to extend the statutory exception from preemption provided by the McCarranFerguson Act to cases where the intent of Congress to preempt state regulation of insurance is explicit in the contested federal law. ${ }^{30}$ The Patient Protection and Affordable Care Act, while perhaps within the judicial exception to McCarran-Ferguson, will eliminate the states' monopoly over intrastate health insurance transactions and severely limit the areas of insurance regulation over which the states could still possibly enjoy the protections of McCarran-Ferguson. In effect, the Patient Protection and Affordable Care Act represents a near-total shift in the locus of insurance regulation from the states to the federal government.

The Act requires that each state establish an "American Health Benefit Exchange" ("Exchange") that "facilitates the purchase of qualified health plans." 31 The Exchange must be either a nonprofit organization or a government agency established by a state. ${ }^{32}$ The exchange must enforce certification standards and procedures for qualified plans in line with federal direction. Plans offered in state Exchanges must be "qualified plans," meaning that they must include benefits at least as extensive as the essential health benefits package established by the Secretary. ${ }^{33}$ The states must cover the cost of benefits required for qualified plans that exceed those required by the essential benefits package. ${ }^{34}$ The Secretary is required to establish a standardized format to present the coverage offered by state exchanges to consumers. ${ }^{35}$ The states must publish this information and provide additional consumer support through a website dedicated to the exchange. The states must also create a phone line for these same purposes. ${ }^{36}$ The states must inform applicants to the exchange of their eligibility for Medicare and Medicaid benefits, and enroll those applicants in such programs when they are identified as eligible. ${ }^{37}$ All the while, the Act gives

29. Scott, supra note 6, at 139 (citing United States v. South-Eastern Underwriters Ass'n, 64 S.Ct. 1162 (1944) and Congress's subsequent passage of the McCarran-Ferguson Act to return regulatory sovereignty over insurance providers to the states).

30. See, e.g., Lander v. Hartford Life \& Annuity Ins. Co., 251 F.3d. 101, 120 (2d Cir. 2001) (holding that the McCarran-Ferguson Act does not foreclose federal preemption where the intent to preempt state regulation of insurance is explicit in the contested federal legislation).

31. Patient Protection and Affordable Care Act $\S 1311,42$ U.S.C. $\S 18031$ (b) (2011).

32. Patient Protection and Affordable Care Act $\S 1311$ (d)(1), 42 U.S.C. $\S 18031$ (d)(1) (2011).

33. Patient Protection and Affordable Care Act $\S 1311(\mathrm{~d})(2)(B), 42$ U.S.C. $\S \S$ 18031(d)(2)(B)(i), (d)(3)(A) (2011).

34. Patient Protection and Affordable Care Act $\$ 1311,42$ U.S.C. $\S$ 18031(d)(3)(B)(ii)(II) (2011).

35. Patient Protection and Affordable Care Act $\S 1311(c)(1) ; 42$ U.S.C. $\S$ 18031(c)(1)(G) (2011).

36. Patient Protection and Affordable Care Act $\S 1311(\mathrm{~d})(4)(B), 42$ U.S.C. $\S$ 18031(d)(4)(B) (2011).

37. Patient Protection and Affordable Care Act $\S 1311(\mathrm{~d})(4)(F), 42$ U.S.C. $\S$ 
the Secretary ultimate regulatory priority over these exchanges, requiring her to establish criteria for certified plans (which are also called "qualified" plans) and set standards for the development of state exchanges. ${ }^{38}$ Further, the Secretary must review and approve state exchanges each year. ${ }^{39}$ The Comptroller General is further directed to conduct a semi-annual study of competition in the health insurance exchanges, and to submit the study to Congress along with recommendations for administrative or legislative changes deemed necessary to increase competition in health insurance exchanges. ${ }^{40}$ No federal funding will be provided to the states in respect to the administration of the Exchanges after January 1, 2015. ${ }^{41}$

The Act also requires states to establish a "Small Business Health Options Program" in which the state assists small businesses in acquiring health insurance for their employees. ${ }^{42}$ States in compliance with the federal regulations may apply for a waiver of this and other provisions to take effect in 2017; however, approval of this waiver is contingent on the state offering health coverage at least as extensive as the essential benefits plan, and offered through an Exchange. ${ }^{43}$ Further, such coverage must include the type of cost-sharing and premium limits outlined in the Act. ${ }^{44}$ Ultimately, the states may elect not to administer the regulatory scheme established in the Act. In such a case, the federal government will assume the "full regulatory burden" of the Act, effectively giving the federal government exclusive regulatory autonomy over that intrastate insurance market. ${ }^{45}$ So even if the states are allowed to opt out, they will nonetheless lose their regulatory autonomy over health insurance, and in turn, serve a diminished

18031(d)(4)(F) (2011).

38. See generally Patient Protection and Affordable Care Act $\S 1321(a), 42$ U.S.C. 18041(a) (2011) (requiring the Secretary to establish standards for state exchanges); Patient Protection and Affordable Care Act § 1331(a), 42 U.S.C. § 18051(a) (2011) (charging the Secretary to review state exchanges and set standards), held unconstitutional as not severable by Florida ex rel. Bondi v. United States Dep't of Health \& Human Servs., No. 3:10-CV91-RV/EMT, 2011 U.S. Dist. LEXIS 22464 (N.D. Fla. Mar. 3, 2011).

39. Patient Protection and Affordable Care Act $\S 1331(f), 42$ U.S.C. $\S 18051(f)$ (2011)

40. Patient Protection and Affordable Care Act $\S 1313(f), 42$ U.S.C. $\S 18033(f)$

41. Patient Protection and Affordable Care Act $\S 1311(a)(4)(B), 42$ U.S.C. $\S$ 18031(a)(4)(B) (2011).

42. Patient Protection and Affordable Care Act $\S 1311(b)(1)(B), 42$ U.S.C. $\S$ 18031(b)(1)(B) (2011).

43. See Patient Protection and Affordable Care Act $\S 1332(a)(1)-(2), 42$ U.S.C. $\S \S$ 18052(a)(1)-(2) (2011).

44. Patient Protection and Affordable Care Act $\S$ 1332(b)(1)(B), 42 U.S.C. $\S$ 18052(b)(1)(B) (2011), held unconstitutional as not severable by Florida ex rel. Bondi v. United States Dep't. of Health \& Human Servs., No. 3:10-CV-91-RV/EMT, 2011 U.S. Dist. LEXIS 22464 (N.D. Fla. Mar. 3, 2011).

45. Florida ex rel. McCollum v. United States Dep't. of Health \& Human Servs., 780 F. Supp. 2d 1256, 1266 (N.D. Fla. 2010) (concluding that the states' commandeering claim related to the health insurance reforms is foreclosed by the fact the states may opt out of their enforcement). 
role in the federal system. Likewise, even if a State is given a waiver, it must still use its political infrastructure to create state law requiring insurance companies to provide the essential benefits package outlined in the Act. Additional laws must be passed or other political action taken to setup the state exchange.

In February 2011, the Empowering States to Innovate Act was introduced in the Senate to move up the effective date of state waivers from 2017 to 2014 . $^{46}$ Despite the name, it does not provide any additional latitude for state innovation. If passed, it would only mean that states that are given waivers would no longer have to enforce the waived provisions in the time between the Act's effective date in 2014 and the waiver's effective date in 2017. The bill has not passed.

As of June 2011, the federal government had granted short-term waivers to the Act's minimum coverage limits for 1,433 separate health plans on the grounds that the provision would force the plan's provider to raise premiums or restrict access to benefits. ${ }^{47}$ September 22, 2011 was the final day for applications to this waiver program. The federal government also granted a waiver to the state of Maine for the provisions requiring insurance providers to spend at least eighty percent of premium dollars on providing health services. ${ }^{48}$ Maine was granted the waiver on the grounds that this requirement would destabilize its insurance market because the requirement would cause a major provider to leave the state network. ${ }^{49}$ The waiver program presents its own constitutional problems by compromising the rule of law and encouraging cronyism.

The Act also requires the states to establish one or more "reinsurance" entities to collect payments from health insurance providers and third party administrators on behalf of group plans, which the reinsurance entity distributes to health insurance providers that cover high-risk individuals in the individual market. ${ }^{50}$ These entities are intended to stabilize premium prices in insurance markets that will no longer be allowed to exclude high-risk

46. See generally Empowering States to Innovate Act, S. 248, 111 th Cong. § 2 (2011).

47. Jason Millman, Program Offering Waivers for Health Benefits is Ending, N.Y. TiMES, June 17, 2011, at A12.

48. Letter from Steven B. Larson, Deputy Adm'r \& Dir., Ctr. for Consumer Info. \& Ins. Oversight, United States Dep't of Health \& Human Servs., to Mila Kofman, Superintendent of Ins., State of Maine Bureau of Ins., Dep't of Prof'1 \& Fin. Regulation (Mar. 8, 2011) (on file with author), available at http://healthreform.kff.org/ /media/Files/KHS/ docfinder/mainewaiver.pdf.

49. Letter from Steven B. Larson, Deputy Adm'r \& Dir., Ctr. for Consumer Info. \& Ins. Oversight, United States Dep't of Health \& Human Servs., to Mila Kofman, Superintendent of Ins., State of Me. Bureau of Ins., Dep't of Prof'l \& Fin. Regulation (Mar. 8, 2011) (on file with author), available at http://healthreform.kff.org/ /media/Files/KHS/ docfinder/mainewaiver.pdf; See Associated Press, Maine Gets Break in Federal Health Care Overhaul, FoxNews.COM, Mar. 9, 2011, Politics: State and Local.

50. Patient Protection and Affordable Care Act $\S 1341$ (b)(1)(A), 42 U.S.C. $\S$ 18061(b)(1)(A) (2011). 
individuals from affordable health plans. ${ }^{51}$ It leaves the Secretary to develop a plan for this stabilization, and to define which insurers must pay into the reinsurance program and how much. ${ }^{52}$ The Act also establishes the Preexisting Condition Insurance Plan. ${ }^{53}$ Under this provision, the Secretary must create a high-risk insurance pool program for individuals with preexisting conditions, and contract with qualified entities (States and nonprofits) to provide immediate access to health insurance for these individuals. $^{54}$ A State may submit an application to Health and Human Services ("HHS") for permission to administer the program, ${ }^{55}$ and an initial allocation of $\$ 5$ billion will be made to each participating state to cover related costs. ${ }^{56}$ All of these changes introduce federal micro-management to intrastate insurance markets.

Title II of the Patient Protection and Affordable Care Act makes changes to the administration of Medicaid and Medicare. One of the largest changes is the expansion of Medicaid eligibility to all individuals under the age of 65 who are not pregnant and not currently eligible for Medicaid or Medicare, and whose income does not exceed $133 \%$ of the poverty line. ${ }^{57}$ The federal government is required to fully fund the medical assistance given to these newly eligible individuals from 2014 through $2016{ }^{58}$ Funding for newly eligible individuals is set at $95 \%$ for $2017,94 \%$ for $2018,93 \%$ for 2019 , and $90 \%$ for 2020 and each year after. ${ }^{59}$ While the newly eligible individuals are nearly completely funded by federal dollars, the Act requires states to stop using disproportionate share considerations in distributing payments to hospitals under a state plan. ${ }^{60}$ As a result, federal Disproportionate Share Hospital ("DSH") payments to States are decreased annually at an aggregate rate of $\$ 500$ million in $2014, \$ 600$ million in each of 2015 and $2016, \$ 1.8$ billion in $2017, \$ 5$ billion in $2018, \$ 5.6$ billion in 2019 , and $\$ 4$ billion in $2020 .^{61}$ These sums will be divided among the states and sub-

51. Id. (requiring reinsurance entity to collect funds that can be redistributed to providers that cover high risk persons, as defined in subsection (b)(2)).

52. Patient Protection and Affordable Care Act $\$ 1341,42$ U.S.C $\$ 18061$ (b)(3) (2011). $\S 1801$.

53. See generally Patient Protection and Affordable Care Act $\S 1101(b)(1), 42$ U.S.C. (2011).

54. Patient Protection and Affordable Care Act $\S 1101(b)(1), 42$ U.S.C. $\S 1800$

55. 45 C.F.R. $\$ 152.6(2011)$.

56. 45 C.F.R. $\$ 152.33$ (2011).

57. Patient Protection and Affordable Care Act $\S 2001(a), 42$ U.S.C. $\S$ 1396a(a)(10)(A)(i)(VIII) (2011).

58. Patient Protection and Affordable Care Act $\S 2001(a)(3), 42$ U.S.C. $\S$ 1396d(y)(1)(A) (2011).

59. Patient Protection and Affordable Care Act $\S 2001(a)(3), 42$ U.S.C. $\S$ 1396d(y)(1)(A)-(E) (2011). (2011).

60. Patient Protection and Affordable Care Act $\S 2551(a), 42$ U.S.C. $\S 1396 r-4(a)(1)$

61. Patient Protection and Affordable Care Act $\S 2551(a), 42$ U.S.C. $\S 1396$ r4(f)(7)(A)(ii)(I)-(VII) (2011). 
tracted from each state's share of Federal medical assistance funding. ${ }^{62}$ In turn, the increase in federal dollars devoted to fund newly eligible Medicaid participants is essentially offset by the decreases in federal distributions under DSH. This means the states will bear new costs under the PPACA, since the increases in federal assistance under the Act are offset by corresponding decreases. In other words, the PPACA forces the states to pay for new entitlements created by the federal government and inhibits the ability of states to compensate hospitals with particularly large numbers of indigent patients. While hospitals heavily dependent on Medicaid reimbursement will still be repaid for a percentage of their costs related to participating patients, these hospitals will no longer be given the full amount of additional compensation represented by DSH. Since Medicaid does not fully reimburse a hospital, DSH payments have been a way to mitigate the cost of serving Medicaid patients. ${ }^{63}$ If states do not make up for missing DSH payments, the care offered at public and private hospitals with large numbers of Medicaid patients will likely suffer. The federal government may counter this assertion by stating that DSH payments are reduced based on the uninsurance rate in the state, and will therefore only affect hospitals in states where most people are paying customers. ${ }^{64}$ However, this argument fails to account for the fact that many newly insured individuals will be Medicaid recipients. In turn, even if uninsurance rates are lower under the new regulatory regime, hospitals will still only receive partial compensation for a large number of newly insured individuals. This leaves them in essentially the same position as before, except without the mitigating factor of DSH payments.

Beyond new fiscal rules, the Act establishes limits on state flexibility regarding Medicaid eligibility standards, payment structure, and state-level administration in general. Each of these limits comes in the form of a condition upon the receipt of federal medical assistance funding. ${ }^{65}$ First, the Act requires states to undertake new enrollment procedures, including the use of digital enrollment and a system that can identify and enroll individuals eligible for Medicaid when they apply for a plan through the state exchange. $^{66}$ As mentioned above, the Act also eliminates existing state-bystate eligibility standards, which often exclude individuals within one hun-

62. Patient Protection and Affordable Care Act $\S 2551$ (a), 42 U.S.C. $\S 1396$ r4(f)(7)(A)(iii) (2011).

63. Evelyne P. Baumrucker et al., Medicaid and CHIP: Changes Made by the Health Care and Education Reconciliation Act of 2010 (HCERA, P.L. 111-152) to the Patient Protection and Affordable Care Act (PPACA, P.L. 111-148), CONG. RES. SERV. (April 1, 2010), available at $\mathrm{http}: / / \mathrm{www} . n c s l . o r g / d o c u m e n t s /$ health/MACHIPchgs.pdf.

64. Id. (2011)

65. Patient Protection and Affordable Care Act $\S 1943,42$ U.S.C. $\S 1396 w-3(a)$

66. Patient Protection and Affordable Care Act $\S 1943$ (b)(a)(A), 42 U.S.C. $\S 1396 \mathrm{w}-$ 3(b)(1)(A) (2011). 
dred percent of the poverty line who are under the age of 65 and not otherwise eligible for Medicaid. The Act requires the States to offer Medicaid enrollees a benchmark policy, which satisfies the essential benefits package determined by the Secretary. ${ }^{67}$ A standard method for calculating the income of applicants for Medicaid called the Modified Gross Income Method is also established, further limiting state flexibility to exclude certain individuals from Medicaid. ${ }^{68}$ The plaintiff states in the Florida proceedings argue in sum that these provisions "infringe on [their] constitutional status as sovereigns, entitled to cooperate with but not to be controlled by the federal government under the Medicaid program." 69

While the Patient Protection and Affordable Care Act contains additional changes, those outlined in this section are the most offensive to the values underlying the establishment of a federalist form of government. ${ }^{70}$ These changes will be further addressed in the following discussion of the state initiated challenges to the Act.

\section{B. State Challenges to the Patient Protection and Affordable Care Act}

Multiple challenges to the Patient Protection and Affordable Care Act have been brought by states in federal court. ${ }^{71}$ One challenge was brought by the Commonwealth of Virginia in the federal court for the state's eastern district. $^{72}$ A separate joint complaint was filed by twenty states in the Northern District of Florida. ${ }^{73}$ The states initially named as plaintiffs in the

67. See generally Patient Protection and Affordable Care Act $\S 1302,42$ U.S.C. $\S$ 18022 (2011) (requiring Secretary to establish standards for essential benefits plan). (2011).

68. Patient Protection and Affordable Care Act $\S 2002,42$ U.S.C. $\S 1396 a(e)(14)$

69. Second Amended Complaint I 60, Florida ex rel. McCollum v. United States Dep't. of Health \& Human Servs., No. 3:10-cv-91-RV/EMT, 2010 WL 247074, at *20 (N.D. Fla. Jan. 18, 2011).

70. See Printz v. United States, 521 U.S. 898, 928 (1997) (citing Brown v. EPA, 521 F.2d 827, 839) (9th Cir. 1975) (explaining that "[p]reservation of the States as independent and autonomous political entities is arguably less undermined by requiring them to make policy in certain fields than ... by 'reducing them to puppets of a ventriloquist Congress"'). The provisions listed in this section make the states into "puppets" of the federal government by putting them in a position where they must either perform expansive vast reforms of intrastate health insurance markets and implement federal regulatory schemes,programmatic undertakings or lose funding for essential public programs and/or their administrative role in the regulation of health insurance. While the states may opt out of the Act's administration, the federal government is still acting as puppet master, as it controls the shape of state level public policy one way or the other.

71. See, e.g., Virginia ex rel. Cuccinelli v. Sebelius, 728 F. Supp. 2 d 768 (E.D. Va. 2010), vacated, 656 F.3d 253 (4th Cir. 2011), petition for cert. filed, No. 11-420 (U.S. filed Sept. 30, 2011); Florida ex rel. Bondi v. United States Dep't of Health \& Human Servs., No. 3:10-cV-91-RV/EMT, 2011 WL 285683 (N.D. Fla. Jan. 31, 2011), aff'd in part, rev'd in part sub nom. Florida ex rel. Atty. Gen. v. United States Dep't of Health \& Human Servs., 656

F.3d 253 (4th Cir.), cert. granted, 80 U.S.L.W. 3199 (U.S. Nov. 14, 2011) (No. 11-398).

72. Virginia ex rel. Cuccinelli v. Sebelius, 728 F. Supp. 2 d 768 (E.D. Va. 2010).

73. Amended Complaint, Florida ex rel. McCollum v. United States Dep't. of Health 
Florida proceedings were: Alabama, Alaska, Arizona, Colorado, Florida, Georgia, Idaho, Indiana, Louisiana, Michigan, Mississippi, Nebraska, Nevada, North Dakota, Pennsylvania, South Carolina, South Dakota, Texas, Utah and Washington. Since filing, six additional states have joined the Florida proceedings-Iowa, Kansas, Maine, Ohio, Wyoming, and Wiscon$\sin ^{74}$ The State of Oklahoma also filed a claim in the U.S. District Court for the Eastern District of Oklahoma in January of 2011. ${ }^{75}$ The combined population of the twenty-six states that have filed suit accounts for about fifty-two percent of all U.S. inhabitants. ${ }^{76}$ Both cases have been decided by a federal district and circuit court, and the multi-state case was granted certiorari by the U.S. Supreme Court on November 14, 2011. This section will first address the Virginia complaint and then move to the multi-state proceedings. Both the district and circuit court decisions will be presented for these cases. The district court's arguments will be presented in the most detail since these holdings address all of the states' arguments, while the circuit courts only reached a narrow part of the dispute. Because the Oklahoma challenge does not raise any additional issues, and because its proceedings are in such a preliminary stage, it will not be addressed in this Note.

The complaint filed by the Commonwealth of Virginia challenges only the individual mandate provisions found in sections 1501 and $5000 \mathrm{a}$ of the Act. ${ }^{77}$ The complaint argues that Congress exceeded its authority under the Commerce Clause by requiring citizens to purchase health care or be fined. ${ }^{78}$ The crux of this position rests on the idea that the Commerce Clause does not extend to non-economic activity, notwithstanding any effect on interstate commerce. ${ }^{79}$ To this end the Commonwealth argues that the decision not to purchase health insurance is not an economic activity or

\& Human Servs., 780 F. Supp. 2d 1256 (N.D. Fla. 2011) (No. 3:10-cv-91-RV-EMT), 2010 WL 2114067.

74. Second Amended Complaint, supra note 69.

75. See Complaint for Declaratory and Injunctive Relief, Oklahoma ex rel. Pruitt v. Sebelius, No. 06:2011-cv-00030 (E.D. Okla. Jan. 21, 2011); see also Press Release, Oklahoma Office of the Attorney General, Oklahoma Attorney General, E. Scott Pruitt Files Federal Lawsuit against Health Care Act (Jan. 21, 2011), available at http://www.oag.state. ok.us/oagweb.nsf/0/BE4CA4E2DD66492E8625781F007AF390!OpenDocument.

76. State and County Quick Facts, U.S. CENSUS BUREAU (last revised Nov. 4, 2010, 12:46 EDT), http://quickfacts.census.gov/qfd/index.html (providing population information via an interactive map).

77. See Complaint for Declaratory and Injunctive Relief $\llbracket 1$, Virginia ex rel. Cuccinelli v. Sebelius, 728 F. Supp. 2d 768 (E.D. Va. 2010) (No. 06:11-cv-00030), 2010 WL 1038397 (laying out the Commonwealth's challenge to the Patient Protection and Affordable Care Act $\$ 1501,42$ U.S.C. $\$ 18091$ (2010)).

78. See id. (citing U.S. v. Lopez, 514 U.S. 549 (1995) and United States v. Morrison, 329 U.S. 598 (2000)) (explaining that these cases struck down the regulation of noneconomic activity as going beyond the outer limits of the Commerce Clause).

79. See id. (quoting Gonzales v. Raich, 545 U.S. 1, 25 (2005)) ("Despite congressional findings that [the regulated subject matter] had an adverse impact on interstate commerce, we held the statute [in Morrison] unconstitutional because, like the statute in Lopez, it did not regulate economic activity."). 
even a non-economic activity, but rather "entirely passive."80 Virginia argues that the "regulation of [such] non-economic activity under the Commerce Clause is possible only through the Necessary and Proper Clause." However, the Necessary and Proper Clause only supplements the authority of Congress when the means implemented to reach the enumerated power are "appropriate," "plainly designed to that end," and "consistent with the letter and spirit of the Constitution." "82 Virginia argues that the individual mandate is not consistent with the underlying principles of the Constitution because it presumes to give Congress power that runs contrary to basic concepts of justice. ${ }^{83}$ Specifically, the Commonwealth speculates that Congress created the individual mandate as a means to fund comprehensive health reform by "making healthy young adults and other rationally uninsured individuals cross-subsidize older and less healthy citizens." 84 The Commonwealth argues that this is akin to a policy which takes the property of $\mathrm{A}$ and gives it to be $\mathrm{B}$, something that American concepts of justice do not tolerate. $^{85}$

Virginia's complaint also claims that the noncompliance penalty provision in section 1501 of the Act is unconstitutional because it "does not meet the historical criteria for a tax." to fall under Congress's Article I, Section 8 tax power, the intended "tax" must have the purpose of generating revenue for the support of the government, while the clear purpose of the noncompliance penalty provision is to regulate behavior, not create revenue. ${ }^{87}$

In response to the Commonwealth's complaint, the federal govern-

80. See id. 117. ring)).

81. See id. $\uparrow 19$ (citing Gonzales v. Raich, 545 U.S. 1, 39 (2005) (Scalia, J., concur-

82. Id. (citing McCulloch v. Maryland, 17 U.S. 316, 421 (1819)).

83. Id. (arguing that "[r]equiring citizen-to-citizen subsidy or redistribution is contrary to the foundational assumptions of the constitutional compact").

84. See id. $\ 13$.

85. See id. \ 20 (quoting Calder v. Bull, 3 U.S. 386, 388 (1798) (plurality opinion) (arguing that "an ACT of the Legislature (for I cannot call it a law) contrary to the great first principles of the social compact, cannot be considered a rightful exercise of legislative authority," and that any policy which takes the property of A and gives it to B does in fact runs contrary to this "great first principle")).

86. Virginia ex. rel. Cuccinelli v. Sebelius, 702 F. Supp. 2d 598, 613 (E.D. Va. 2010) vacated, 11-1057, 2011 WL 3925617 (4th Cir. Sept. 8, 2011) (referencing the Commonwealth's definition of a tax).

87. See Reply Memorandum in Support of Plaintiff's Motion for Summary Judgment at 8, Virginia ex rel. Cuccinelli v. Sebelius, 702 F. Supp. 2d 598 (E.D. Va. 2010) (No. 3:10CV188), 2010 WL 3952341 (citing United States v. Reorganized CF\&I Fabricators of Utah, Inc., 518 U.S. 213 (1996)) (stating that a "tax is an enforced contribution to provide for the support of government"); see also Plaintiff's Memorandum in Support of Motion for Summary Judgment at 20, Virginia ex rel. Cuccinelli v. Sebelius, 702 F. Supp. 2d 598 (E.D. Va. 2010) (No. 3:10cv188), 2010 WL 3536788 (citing Sunshine Anthracite Coal Co. v. Adkins, 310 U.S. 381, 393 (1940)) (holding that to pass constitutional muster, a penalty must be used to further a constitutionally enumerated power). 
ment argues that the individual mandate falls within the traditional scope of Congress's regulatory powers under the Commerce Clause. ${ }^{88}$ The defendant's argument is essentially that "the sum of individual decisions to participate or not in the health insurance market has a critical effect on interstate commerce," and in turn draws these decisions within the definition of economic activity properly regulated under the commerce clause. ${ }^{89}$ In support of this position, the government likens the requirement to purchase insurance with its regulation of non-commercial wheat growers in Wickard $v$. Filburn. $^{90}$ Additionally, the federal government argues the penalty imposed for failure to meet the individual mandate is within Congress's Article I, Section 8 power to tax and spend. ${ }^{91}$ The defendant argues that the mandate falls within Congress's power to tax as a means to provide for the "general welfare," and can therefore be checked only by the electorate. ${ }^{92}$

In August of 2010 the district court denied the federal government's motion to dismiss. ${ }^{93}$ In December the district court granted the Commonwealth of Virginia's motion for summary judgment. ${ }^{94}$ The court prefaced this latter decision by noting "[d]espite the laudable intentions of Congress in enacting a comprehensive and transformative health care regime, the legislative process must still operate within constitutional bounds." 95 As it

88. Reply Memorandum in Support of Defendant's Motion for Summary Judgment at 11, 15, Virginia ex rel. Cuccinelle v. Sebelius, 702 F. Supp. 2 d 598 (E.D. Va. 2010 ) (No. 3:10-cv-00188), 2010 WL 3952346 (claiming that the individual mandate is within Congress's commerce clause power because it "regulates conduct with substantial effects on interstate commerce" and arguing, in addition, that the individual mandate is essential to achieve the Act's larger reforms, and that the decision in Gonzales $v$. Raich supports the idea that "Congress has the authority to take those measures that it rationally finds necessary to give effect to its regulation of interstate commerce").

89. Virginia ex rel. Cuccinelli v. Sebelius, 702 F. Supp. 2d 598, 609 (E.D. Va. 2010).

90. Id. (citing Wickard v. Filburn, 317 U.S. 111 (1942)) (holding that while noncommercial wheat growers are not engaged in interstate commerce, their production effects supply and demand curves of the lager market, and in turn Congress is justified in regulating their production of wheat). In the present case the government argues that the Wickard decision applies to the individual mandate because by not buying insurance, the uninsured have an impact on the cost of insurance and health care in general.

91. Id. at 612 (outlining the defendant's argument that the penalty is within Congress's power to tax and spend because the legitimate exercise of such power depends on the measure being a means to raise revenue and reasonably related to the ultimate end of the associated regulation).

92. Memorandum in Support of Defendant's Motion for Summary Judgment at 40, Virginia ex. rel. Cuccinelli v. Sebelius, 702 F. Supp. 2d 598 (E.D. Va. 2010) (No. 3:10-CV00188), 2010 WL 3536789 (relying on United States v. Kahriger, 345 U.S. 22 (1953) (defining a broad tax power under Article 1, Section 8 of the U.S. Constitution), overruled in part on other grounds by Marchetti v. United States, 390 U.S. 39 (1968)).

93. Virginia ex rel.Cuccinelli v. Sebelius, 702 F. Supp. 2d 598, 612 (E.D. Va. 2010) (No. 3:10CV188) (denying the motion on grounds that the plaintiff's complaint "advances a plausible claim with an arguable legal basis").

94. See generally Virginia ex. rel. Cuccinelli v. Sebelius, 728 F. Supp. 2d 768 (E.D. Va. 2010).

95. Id. at 779-780 (setting up the discussion of the boundaries of Congress's commerce clause power). 
relates to this case, these constitutional bounds are the "outer limits" of the commerce clause. ${ }^{96}$ The court concluded that to pass a constitutional challenge, the target of the regulation must be economic in nature, it must affect interstate commerce, and it must be an "activity." 97 In this context, the court decided that the decision not to enter the health care market is outside the historical scope of the commerce clause. ${ }^{98}$ The court also concluded that the penalty attached to the mandate is not a tax, but rather a penalty. ${ }^{99}$ As a penalty not attached to the exercise of an enumerated power, the measure is not constitutional. ${ }^{100}$ In sum, the court found the individual mandate and corresponding penalty unconstitutional but declined to enforce an injunction against the enactment of the provisions at this time.

The United States Court of Appeals for the Fourth Circuit reversed the district court's decision for lack of standing. ${ }^{101}$ The court held that the Commonwealth's assertion of standing via the conflict between the federal mandate and the Virginia law prohibiting the forced procurement of health insurance is insufficient to establish standing. Specifically, the court argues that the conflict of laws does not satisfy the "irreducible constitutional minimum of standing" laid out in Lujan v. Defenders of Wildlife, which requires a plaintiff to demonstrate that: (1) it has suffered an injury in fact; (2) there is a causal relationship between the injury and the conduct complained of; and (3) a favorable ruling will likely redress that injury. ${ }^{102}$ The circuit court held that Virginia suffered no cognizable harm because the individual mandate applies to individual citizens, and places no burden on the Commonwealth of Virginia. ${ }^{103}$ The court explained that to satisfy the injury in fact prong of the Lujan standard of standing, the Commonwealth must "demonstrate that the individual mandate . . . 'invades' its 'legally protected

96. Id. at 780-782 (citing limits placed on Congress's Commerce Clause power by three cases: Wickard v. Filburn, 317 U.S. 111 (1942) (arguing that the regulated activity in this case was within Congress's authority under the Commerce Clause because the activity was the product of a "self-directed affirmative move," which "self-initialed change of position voluntarily placed the subject within the stream of interstate commerce"); United States v. Morrison, 529 U.S. 598 (2000); United States v. Lopez, 514 U.S. 549, 561-562 (1995)).

97. Cuccinelli, 728 F. Supp. 2d at 781 (E.D. Va. 2010) (arguing that precedent shows that regulatory authority under the commerce clause must be "triggered by some type of selfinitiated action").

98. Id. at 782 (concluding that Congress can only regulate "self-initiated action," and that the decision not to purchase health insurance is not a self-initiated action).

99. Id. at 786-788 (concluding that the noncompliance penalty is in fact a penalty and not a tax, because it was repeatedly referred to as a penalty during and before the trial, and to be a tax Congress must intend it to be revenue raising measure).

100. Id. at 788 (E.D. Va., 2010) (citing Sunshine Anthracite Coal Co. v. Adkins, 310 US 381, 393 (1940)).

101. Virginia ex rel. Cuccinelli v. Sebelius, 656 F.3d 253, 270 (4th Cir. 2011) (holding that Virginia suffered by cognizable harm through the passage of the Patient Protection and Affordable Care Act).

102. Id. at 268 (citing Lujan v. Defenders of Wildlife, 504 U.S. 555, 560 (1992)).

103. Id. 
interest,' in a manner that is both 'concrete and particularized' and 'actual or imminent." 104 In this regard, the Commonwealth asserted that the individual mandate interferes with or commandeers its sovereign capacity to enforce duly passed state laws, and thereby imposes a cognizable harm sufficient to establish standing. ${ }^{105}$ The circuit court, however, concluded that the Virginia law prohibiting forced purchase of health insurance merely attempts to immunize state citizens from federal law, and is not an assertion of sovereign power, as the Commonwealth lacks the sovereign capacity to nullify federal law. ${ }^{106}$ In this way, the circuit court argues, the enforcement of the Virginia law is stifled not by the mandate provision of the Patient Protection and Affordable Care Act, but by the Supremacy Clause of the U.S. Constitution. ${ }^{107}$ As argued, the Commonwealth's assertion of standing therefore fails because a legitimate exercise of state sovereignty was not hindered by the challenged federal law, as is required to establish standing on the grounds of state sovereignty. Since standing was denied, the Fourth Circuit decision did not reach the constitutionality of the individual mandate. On this point, and as an important aside before moving on to the multi-state case, it should be noted that the Fourth Circuit decision was based solely on the standing arguments related to Virginia's challenge to the individual mandate. Sovereignty standing may exist in regards to a state's challenge of the Medicaid and insurance industry reforms-provisions that Virginia did not challenge.

In fact, the federal government conceded such standing in the multistate case decided by the Eleventh Circuit and challenged plaintiff states' standing only in regards to the individual mandate. ${ }^{108}$ Like the Fourth Circuit, the Eleventh Circuit saw the standing of the plaintiff states with regards to the individual mandate as problematic. ${ }^{109}$ However, the Eleventh Circuit avoided the question by holding that since individual plaintiffs had standing on the matter the law did concern itself with finding additional sources of standing for the plaintiff states. ${ }^{110}$

Substantively, the complaint brought by multiple states in the Northern District of Florida offers some insight into judicial posture regarding the more abstract federalist issues surrounding the Patient Protection and Affordable Care Act. The complaint alleges six counts, four of which are relevant to this discussion, and only two of which survived the defendant's

104. Id.

105. Id.

106. Id. at 270

107. Virginia ex rel. Cuccinelli v. Sebelius, 656 F.3d 253, 270 (4th Cir. 2011).

108. Florida ex rel. Bondi v. United States Dep't. of Health \& Human Servs., 648 F.3d 1235, 1243 (11th Cir. 2011).

109. Id. (admitting that 'the question of the state plaintiffs' standing to challenge the individual mandate is an interesting and difficult one").

110. Id. 
initial motion to dismiss. ${ }^{111}$ Two of these counts evoke the anticommandeering rule. Count one and two claim that the individual mandate found in section 1501 of the Act is unconstitutional. ${ }^{112}$ This count was ultimately used to hold the entire statute unconstitutional. ${ }^{113}$ The arguments in favor and against this position are essentially the same as those addressed in the Virginia proceedings, and therefore they will not be repeated. Notwithstanding the complete invalidation of the Act through the nonseverability of the individual mandate, it is still important to review the findings of the court as they relate to the remaining counts. This is because the court did not find those provisions unconstitutional, and in turn did not apply related judicial concepts of federalism in a manner that truly protects state regulatory autonomy.

The third count is that the noncompliance penalty attached to the individual mandate is unconstitutional. ${ }^{114}$ Plaintiffs here take a different approach than was taken in the Virginia case. They argue that the penalty used to enforce the individual mandate is a direct tax in violation of Congress' taxing powers per Article 1 , Sections 2 and 9 of the Constitution. ${ }^{115}$ However, the states cover their bases in count one by arguing that the noncompliance fee is in fact a penalty and therefore unconstitutional because it is intended to generate revenue. ${ }^{116}$ The court ultimately dismissed the claim that the penalty is a direct tax and held that it is instead a penalty. ${ }^{117}$

The next count that is relevant to this discussion is that the Act violates the anti-commandeering rule by taking away state regulatory discretion in the administration of Medicaid and forcing new administrative and financial burdens on the states. ${ }^{118}$ The states claim that the regulatory and related financial burdens placed on them by the Act violate the $9^{\text {th }}$ and $10^{\text {th }}$ Amendments and the "constitutional principles of federalism and dual sovereignty on which this Nation was founded." 119 Further, the states argue the regulatory obligations violate their sovereignty and right to republican government under Article IV, Section 4 of the Constitution (the Guaranty Clause). ${ }^{120}$ Lastly, they argue that the choice to either submit to changes in

111. See Order and Memorandum Opinion (Defendant's Motion to Dismiss), Florida ex rel. McCollum v. United States Dep't. of Health \& Human Servs., 716 F. Supp. 2d 1120, 1165 (N.D. Fla. 2010).

112. Second Amended Complaint, supra note 69, at $169-78$.

113. Florida ex rel. Bondi v. United States Dep't of Health \& Human Servs., $780 \mathrm{~F}$. Supp. 2d 1256, 1299-1305 (N.D. Fla. 2011).

114. Second Amended Complaint, supra note 69, at $979-82$.

115. Id. ๆ 80 .

116. Id. $\ 73$.

117. Order and Memorandum Opinion (Defendant's Motion to Dismiss), Florida ex. rel. McCollum v. United States Dep't. of Health \& Human Servs., 716 F. Supp. 2d 1120, 1140 (N.D. Fla. 2010).

118. Second Amended Complaint, supra at note 69, at $\rrbracket 83-86$.

119. Id. 86.

120. Id. $\ 83-86$. 
Medicaid or opt out of Medicaid and lose related federal funding, meets the threshold described in Steward Machine Co. v. Davis, ${ }^{121}$ where "Congressional pressure turns into impermissible coercion." 122 The states frame this option as a Hobson's choice, wherein no real choice is given at all. ${ }^{123}$ The states must either accept the changes to Medicaid, or give up federal funding for a program that serves millions of its needy citizens, and which they cannot sustain financially with the limited revenue sources available to them. ${ }^{124}$ In its order granting summary judgment, the court ruled that the changes to Medicaid were within Congress's spending power, and therefore constitutional. ${ }^{125}$

The final count discussed in the complaint is the most important for this Note, as much for the fact that it did not survive defendant's motion to dismiss as for its substance. The plaintiffs claim that through the regulatory scheme set forth in the Act, Congress commandeers state regulatory infrastructure and violates state sovereignty. ${ }^{126}$ The argument is that the Act will "displace State authority over a substantial segment of intrastate insurance regulation . . . that the States have always possessed under the police powers provided in the Constitution . . ..."127 The states rely on the two definitive cases for the anti-commandeering rule, New York $v$. United States and Printz v. United States. ${ }^{128}$ The states explain that "the[] Supreme Court invalidated both [regulatory] schemes [in New York and Printz] based on the Constitution's federal architecture and the States' role as dual sovereigns in that structure." 129 Plaintiffs asked the court to enjoin the enforcement of the regulatory scheme contained in the Act.

In its initial decision on defendant's motion to dismiss, the courts dismissed all counts but those related to the Commerce Clause and the commandeering claim related to Medicaid reforms. The court's decision to

121. Steward Machine Co. v. Davis, 301 U.S. 548 (1937).

122. Florida ex rel. McCollum v. United States Dep't of Health \& Human Servs., 716 F. Supp. 2d at 1157 (citing Steward Machine Co. v. Davis, 301 US 548, 590 (1937)) (reasoning that, notwithstanding the federal government's power to attach conditions on money distributions to the states, some situations may arise where the conditions are not coercion but unlawful compulsion).

123. Memorandum in Support of Plaintiff's Motion for Summary Judgment at 25, Florida ex rel. McCollum v. United States Dep't of Health \& Human Servs., 716 F. Supp. 2d 1256 (N.D. Fla. 2010) (No. 3:10-cv-91-RV/EMT), 2010 WL 4564355.

124. Id. at 25 .

125. Florida ex rel. Atty. Gen. v. United States Dep't of Health \& Human Servs., 780 F. Supp. 2d 1256, 1267-70 (N.D. Fla. 2011) (sympathizing with, but not holding as dispositive, the burdens placed on states by the Medicaid provisions of the Act), order clarified, 780 F. Supp. 2d 1307 (N.D. Fla. 2011) and aff'd in part, rev'd in part sub nom. Florida ex rel. v. United States Dep't of Health \& Human Services, 648 F.3d 1235 (11 th Cir. 2011). )

126. See, e.g., Second Amended Complaint, supra note 69, at $₫ 88$.

127. Id. I 44.

128. Memorandum in Support of Plaintiff's Motion for Summary Judgment, supra note 123 , at 21 .

129. Id. at 25 . 
dismiss the commandeering count related to the establishment of American Health Benefit Exchanges is the most important for the purposes of this Note. Given existing judicial applications of the anti-commandeering rule, it is not surprising that the claim was dismissed. Commandeering cases have limited the rule's protection to those cases where Congress forces the states to use their legislatures to pass a statutory scheme in an area not previously regulated by the states. ${ }^{130}$ That is, commandeering applies only where federal law requires the states to pass a law in an area previously unregulated by the states, and in effect controls the manner in which the states regulate their citizens. ${ }^{131}$ As applied, the anti-commandeering rule does not protect state law from being preempted by federal legislative schemes that give the states the option to carry out their provisions or allow the federal government to administer them on the states' behalf. ${ }^{132}$ This forecloses the states' claim under the Act, as it leaves regulation to the federal government should the states opt to decline participation. ${ }^{133}$ This point of law requires some further elaboration because it raises important issues related to constitutional values of federalism.

As application of the anti-commandeering rule demonstrates, duly passed federal law will always preempt state law under the Supremacy Clause. However, the Supremacy Clause should not be applied to allow Congress to use its spending power to transform the states into bureaucratic vassals of a federal liege. This is especially so in the context of the anticommandeering rule, which has the stated purpose of promoting the constitutional rule that the states are not "regional offices nor administrative agencies" of the federal government. ${ }^{134}$ This point will be used to criticize existing Tenth Amendment jurisprudence in the proceeding sections. How-

130. See, e.g., Hodel v. Virginia Surface Mining \& Reclamation Assn., Inc., 452 U.S. 264, 288-291 (1981) (denying the plaintiff state's commandeering claim on the grounds that the challenged statute did not force the states to assume its underlying regulatory scheme and concluding further that the 10th Amendment does not protect state laws passed under the general police power from being displaced by federal laws passed under the Commerce Clause); see also Printz v. United States, 521 U.S. 898, 929 (1997) (holding that commandeering occurs where the states are forced to adopt a federal policy scheme, but does not occur where Congress has simply "imposed preconditions to continued state regulation of an otherwise pre-empted field").

131. Order and Memorandum Opinion (Defendant's Motion to Dismiss), Florida ex rel. McCollum v. United States Dep't of Health \& Human Servs., 716 F. Supp. 2d 1120, $1155-1156$ (N.D. Fla. 2010) (referencing Hodel v. Virginia Surface Mining \& Reclamation Assn., Inc., 452 U.S. 264 (1981)) (arguing that commandeering is not applicable to cases where Congress preempts state regulation and gives states the option not to participate in the scheme).

132. See Hodel, 452 U.S. at 288.

133. Order and Memorandum Opinion (Defendant's Motion to Dismiss), Florida ex rel. McCollum v. United States Dep't of Health and Human Servs., 716 F. Supp. 2d 1120, 1154 (N.D. Fla. 2010) (dismissing the commandeering claim related to the American Health Benefit Exchanges).

134. New York v. United States, 505 U.S. 144, 188 (1992). 
ever, the finding of constitutionality as to Congress's exercise of its spending power also raises a potential discrepancy with existing applications of the law. Jonathan Adler notes that while citizens who purchase insurance from state operated exchanges are given a federal tax credit to help recoup their costs, citizens who purchase insurance from a federally operated exchange are not given this credit. ${ }^{135}$ So where a state opts out of participation in the Act, the federal government will deny its citizens the tax benefits given to similarly situated citizens in states which administer their own exchanges. There is no case law that allows the federal government to condition spending directed at individual citizens on that citizen's state of domicile enforcing a federal regulation. If nothing else, this type of pressure is politically unsavory and offensive to the rule of law.

Notwithstanding its ultimate invalidation of the Act, the district court's decision did very little to expand protections of state regulatory autonomy. If not for the finding of non-severability, only the individual mandate would have been voided while every provision challenged under the anti-commandeering rule would remain in force. This outcome prohibits a specific exercise of federal power, i.e., a requirement to purchase health insurance, but fails to prevent the federal government from assuming even greater and more constitutionally offensive authority through the Act's establishment of a broad regulatory scheme, and use of state governments as administrative tools. On the issue of the Act's overall validity, the district court concluded:

If Congress intends to implement health care reform-and there would appear to be widespread agreement across the political spectrum that reform is needed-it should do a comprehensive examination of the Act and make a legislative determination as to which of its hundreds of provisions and sections will work as intended without the individual mandate, and which will not. It is Congress that should consider and decide these quintessentially legislative questions, and not the courts. ${ }^{136}$

In sum, while the whole Act was invalidated by the Florida district court, only the individual mandate was found unconstitutional. The court found legal support for the remaining provisions, which were annulled only through the non-severability of the individual mandate. In reaching this

135. Jonathan H. Adler, Cooperation, Commandeering, or Crowding Out?: Federal Intervention and State Choices in Health Care Policy, 20 KAN. J.L. \& PUB. PoL'Y 199, 214 (2011).

136. Florida ex rel. Bondi v. United States Dep't of Health \& Human Servs., $780 \mathrm{~F}$. Supp. 2d 1256, 1305 (2011). 
decision, the district court was bound by precedent. In fact, the court acknowledged and bemoaned its inability to address the threat to federalism posed by Congress's coercive use of its enumerated powers, specifically in relation to Medicaid reforms. ${ }^{137}$

The importance of the non-severability finding by the district court is brought to the forefront by the Eleventh Circuit Court's reversal of this finding, and ultimate holding that the individual mandate is unconstitutional, but is severable from the Patient Protection and Affordable Care Act's remaining provisions, all of which the circuit court found constitutionally valid. $^{138}$ For example, the Circuit Court held that the Act's Medicaid provisions did not exceed Congress's Article I spending power. ${ }^{139}$ The court concluded that the constitution allows Congress to attach conditions on its distribution of federal funds to the states. ${ }^{140}$. While it acknowledged the existence of a Tenth Amendment limit on the coercive use of this power, the circuit court concluded that the Act's Medicaid provisions did not fall beyond this federalist limit. ${ }^{141}$ Specifically, the Eleventh Circuit concluded that the Medicaid amendments were not unconstitutional as "unduly coercive," because the Medicaid Act allowed the federal government to make amendments at the time the states agreed to enter the regulatory partnership, and because no such amendment had ever been found unconstitutional for conditioning federal funding on state compliance, though several past amendments had done exactly that. ${ }^{142}$ The circuit court also argued that the Medicaid provisions were not coercive because a majority of the funding burden created by the Act would be funded by the federal government. ${ }^{143}$ Lastly, the circuit court argued that the Medicaid amendments were not coercive because the Act gave the states four years' notice of its regulatory changes, which is sufficient time for the states to decide whether or not to continue participation in the Medicaid program. ${ }^{144}$ In short, the circuit court's remaining arguments in regards to commandeering largely followed the same reasoning employed by the district court in disposing of these claims. The legal theory involved with these claims will be addressed in more detail in the following section.

137. Id. at 1266 (concluding that Congress's use of the Spending Clause to encourage the states to implement the Act's changes to Medicaid was contrary to traditional views of state and federal power sharing, and would not be tolerated if not supported by existing Supreme Court case law).

138. See generally Florida ex rel. Bondi v. United States Dep't of Health \& Human Servs., 648 F.3d 1235 (11th Cir. 2011).

139. Id. at 1267.

140. Id. (justifying the Act's conditions on Medicaid funding on the grounds that past Medicaid reforms also used conditional spending to ensure their implementation).

141. Id. at $1267-1269$.

142. Id. at $1267-1268$.

143. Id. at 1268 .

144. Florida ex rel. Bondi v. United States Dep't of Health \& Human Servs., 648 F.3d 1235, 1268 (11th Cir. 2011). 
Returning to the disposition of the individual mandate, the Eleventh Circuit concluded that the mandate was unconstitutional, but was severable from the remaining provisions. ${ }^{145}$ Thus, the circuit court found the individual mandate unenforceable, but left the Act's remaining provisions in force. The Eleventh Circuit cited the Supreme Court's "well-established" rule for severability that "unless it is evident that the legislature would not have enacted those provisions which are within its power, independently of that which is not, the invalid part may be dropped if what is left is fully operative as law."146 First, the unconstitutional provision should be used to render the whole law invalid where it is evident that Congress would not have adopted the valid provisions of the law independently of adopting the unconstitutional provision. Second, where it is not so evident, a finding of non-severability should only be reached where after removing the unconstitutional provision, the valid provisions are not "fully operative as a law." The circuit court applied the latter rule (the "operative as law" rule) to all but two of the Act's remaining provisions. Two of the Act's industry reforms were subjected to the first rule of non-severability, striking down valid provisions where it is evident that they would not have been adopted if not for the adoption of the unconstitutional provision. In applying the "fully operative" rule, the court summarily concluded that the remaining provisions stood alone from the individual mandate and were independently "operative as a law."147 As for two industry reforms - the guaranteed issue requirement and the prohibition on preexisting condition exclusions-the court found the provisions were "independently operative as law," but questioned whether they would have been adopted absent the individual mandate. $^{148}$ The Circuit Court referenced legislative record in which Congress recognized that the individual mandate was essential to the larger industry reforms. ${ }^{149}$ The forced purchase of insurance by healthy individuals would help mitigate the cost born by insurers through the Act's requirement that they accept all applicants for insurance, and not exclude any applicant based on a pre-existing condition. ${ }^{150}$ However, the circuit court found that these reforms were not dependent on the individual mandate because no cross-

145. Id. at 1328.

146. Id. at 1321 (quoting Alaska Airlines v. Brock, 480 U.S. 678, 684 (1987) (emphasis added) (highlighting the degree of certainty necessary to find valid provisions of an act nonseverable from an unconstitutional provision).

147. Id. at 1332-1333.

148. Id. at 1323 .

149. Florida ex rel. Bondi v. United States Dep't of Health \& Human Servs., 648 F.3d 1235, 1332 (11th Cir. 2011) (citing 42 U.S.C. 18091(a)(2)(I)) (stating that the individual mandate is "an essential part of [Congress's] larger regulation of [the insurance industry], and the absence of the requirement would undercut Federal regulation of the health insurance market").

150. Id. at 1317 (citing 42 U.S.C. $18091(\mathrm{a})(2)(\mathrm{J})$ ) (stating that "the [individual mandate] is essential to creating effective health insurance markets that do not require underwriting and eliminate its associated administrative costs"). 
reference to the individual mandate was present in the provisions of the reforms, and because Congress did not include a non-severability clause requiring the two reforms to be removed if the mandate is found invalid. ${ }^{151}$ Ultimately, the court stated the remedial question on the issue to be whether the intent of Congress in passing the Patient Protection and Affordable Care Act is better furthered by (1) the Act enforced with all provisions except the individual mandate, or (2) the Act enforced without both the individual mandate and the two industry reforms. ${ }^{152}$ The Eleventh Circuit concluded that the two reforms further the fundamental purpose of the Act to make health insurance more accessible and thereby reduce the number of uninsured. ${ }^{153}$ Removing these provisions would reintroduce restrictions on access to health insurance and therefore reduce the Act's impact on increasing access to insurance and reducing the number of uninsured. ${ }^{154}$ Therefore, the court concluded that the individual mandate is severable from all remaining provisions of the Patient Protection and Affordable Care Act.

Together, these challenges to the Patient Protection and Affordable Care Act reflect an effort by the states to assert a strong, viable role within the federalist balance of power. As may already be evident, existing jurisprudence makes this a difficult task. Beginning with the anticommandeering rule, the following section will outline the current law as it relates to the promotion of state autonomy, and the distribution of power under the federal constitution.

\section{THE CURRENT STATE OF FEDERALIST JURISPRUDENCE}

Federalism refers to the Constitution's vertical diffusion of power between the states and the federal government. ${ }^{155}$ It is embodied in the specific enumeration of federal power and the reservation of all remaining authority to the states and the people. This structure is essential to constitutional governance. It ensures that no single sovereign can aggregate the necessary power to oppress liberty or deny the people their express right to a republican form of government. As a negative document, the Constitution uses the specific enumeration of federal power to confine the federal government's authority to limited circumstances. The states and the people are left with the authority over the remaining regulatory areas. Because the states are the closest regulatory sovereign to the people, they must exercise their broad police power in a manner that does not offend the people's political preferences. Where those preferences are offended, a new state government can be elected, which in turn has the capacity to change policy

151. Id. at 1324.

152. Id. at $1324-1325$.

153. Id.

154. Id. at 1325 .

155. See, e.g., Gerald G. Ashdown, Federalism's Floor, 80 Miss. L.J. 69, 70 (2010). 
directions. ${ }^{156}$ The states likewise send representatives to the federal government to create national policy that is in line with state interests. This protects the people of the several states from having their preferences ignored at the federal level, and gives the federal government an inherent political link to the states. Where issues of national import exist, that no single state can address, the federal government has sovereign capacity to act. ${ }^{157}$ The federal government also protects the Constitutional rights of the people from violation by the states. ${ }^{158}$

This balance requires strong states with regulatory sovereignty that can be abrogated only where "national exigency" requires and only in a manner consistent with the text of the Constitution and the principles and values which that text is designed to promote. This section will outline how the federalist structure of government is applied under existing jurisprudence. It will demonstrate the failure of modern jurisprudence to effectuate the constitutional system of government defined above.

\section{A. The Anti-Commandeering Rule}

The anti-commandeering rule was introduced by New York $v$. United States. ${ }^{159}$ However the outer limits of the rule were discussed eleven years prior in Hodel v. Virginia Surface Mining \& Reclamation Ass' $n$, Inc. ${ }^{160}$ In Hodel, the state challenged a federal law requiring it to enact and administer a regulatory program over the surface coal mining industry. ${ }^{161}$ The challenge alleged that the law was outside Congress's Commerce Clause powers and violated the Tenth Amendment. The Supreme Court found no merit in either argument. The Court concluded that the law did not exceed Congress's Commerce Clause powers because the record substantiated that local surface coal mining activity had an important impact on interstate commerce, and because the law had a rational relationship to the goals Congress sought to accomplish. ${ }^{162}$ As for the Tenth Amendment, the court concluded:

[T]he Tenth Amendment does not limit congressional

156. See generally id. at 79 (arguing that the purpose of federalism is to protect the state's capacity to respond to local preferences).

157. See, e.g., Robert D. Cooter and Neil S. Siegal, Collective Action Federalism: A General Theory of Article 1 Section 8, 63 STAN. L. REv. 115, 116 (2010) (arguing that federal power should be limited by examining if the regulated issue requires collective action).

158. See, e.g., Ashdown, supra note 155, at 83-84.

159. New York v. United States, 505 U.S. 144 (1992).

160. Hodel v. Virginia Surface Mining \& Reclamation Ass'n., Inc., 452 U.S. 264, 288 (1981) (concluding that commandeering does not apply to federal laws that give the states the option to participate or transfer authority to the federal government).

161. Id. at 288.

162. Id. at 265 . 
power to preempt or displace state regulation of private activities affecting interstate commerce. Moreover, Congress does not invade areas reserved to the States by the Tenth Amendment simply because it exercises its authority under the Commerce Clause in a manner that displaces the States' exercise of their police powers. ${ }^{163}$

Further, the Court found that the states were not forced to regulate, because they were left free to opt out of the regulatory scheme and allow the federal government to assume the regulation for them. As a result, there was no commandeering. ${ }^{164}$

New York $v$. United States was the first case to expressly outline the anti-commandeering rule. ${ }^{165}$ The State of New York challenged a federal law that required the state's legislature to either pass a law allowing for the establishment of a nuclear waste treatment facility within the state, or take title to any nuclear waste within its borders. ${ }^{166}$ The Court referenced Hodel, stating that the anti-commandeering rule applies where the challenged federal act "commandeers the legislative processes of the States by directly compelling them to enact and enforce a federal regulatory program." ${ }^{167}$ The court framed this rule as a protection of the "Constitution's plan for the allocation of intergovernmental authority," inclusive of an understanding that the Constitution gave to the states a degree of sovereignty so that they could not be treated as "regional offices nor administrative agencies" of the federal government. ${ }^{168}$ The Court stated that "while Congress has substantial powers to govern the Nation directly, including in areas of intimate concern to the States, the Constitution has never been understood to confer upon Congress the ability to require the States to govern according to Congress' instructions." 169 The Court noted that this rule did not stop Congress from pre-empting state law. ${ }^{170}$ These are the two exceptions to the anticommandeering rule mentioned in Hodel.

The next anti-commandeering case was Printz v. United States. ${ }^{171}$ Here the Court struck down portions of the Brady Handgun Violence Pre-

163. Id.

164. Id. at 288.

165. See generally New York v. United States, 505 U.S. 144 (1992).

166. Id. at 154 .

167. Id. at 176 (citing Hodel v. Virginia Surface Mining \& Reclamation Ass'n., Inc., 452 U.S. $264,288(1981))$.

168. Id. at 147,188 .

169. Id. at 162 .

170. Id. at 145; see also Hodel v. Virginia Surface Mining \& Reclamation Ass'n., Inc., 452 U.S. 264, 288-93 (1981) (allowing the preemption of state law by federal law that does not force state regulatory participation).

171. Printz v. United States, 521 U.S. 898 (1997). 
vention Act that required state and local law enforcement officials to conduct background checks on prospective handgun buyers. ${ }^{172}$ The Court held that the Brady Handgun Act's requirement that state officials administer background checks violated the Constitutional concept of dual sovereignty. On this point, the Court concluded that " $[t]$ he power of the Federal Government would be augmented immeasurably if it were able to impress into its service - and at no cost to itself-the police officers of the 50 States."173

The case of Reno $v$. Condon ${ }^{174}$ refused to apply the anticommandeering rule where the challenged federal law set federal requirements for existing state regulations. This narrowed commandeering to situations where the federal law requires the states to undertake new regulatory activities by passing laws or assisting in the administration of federal policy. ${ }^{175}$ This case is supported by the earlier case of South Carolina $v$. Baker. ${ }^{176}$

In sum, the anti-commandeering rule is intended to protect the intentionally federalist balance of powers created by the U.S. Constitution. However, these cases show that the anti-commandeering rule applies only where the federal government forces the states to undertake new regulation, but is not applicable where the option is given for the states to submit administration of the law to federal control, or where a generally applicable federal law preempts state law in an area of plenary Congressional power. Further, it does not stop the federal government from treating the states likes bureaucratic agencies of the federal government so long as the states are allowed to either administer the federal program or give up all participation in the regulatory area. The federal government lacks both the sovereign and logistical capacity to implement broad federal programs on the state level without extensive state participation in administrating those programs. Supplementing federal capacity to regulate by using the bureaucratic infrastructure of the states to implement substantive federal policy defeats the purpose of creating separate regulatory spheres for the state and federal governments, and compromises the political autonomy of the States which is necessary to effectuate the system of government embodied in the Constitution.

\section{B. Other Important Concepts to Federalist Jurisprudence}

A review of federalist jurisprudence serves to show the inadequacy of

172. See generally id.

173. Id. at 902.

174. Reno v. Condon, 528 U.S. 141 (2000).

175. Id. at $150-51$.

176. See generally South Carolina v. Baker, 485 U.S. 505, 505-506 (1988) (holding that no commandeering occurs where the federal government does not force states to regulate citizens). 
protections for state autonomy and the judiciary's preference for federal power. In formulating a judicial rule to protect the values of federalism, it is necessary to understand the manner in which power is balanced under existing law. Federalism depends as much on having a strong national government as it does on securing the autonomy of the states. ${ }^{177}$ Any rule which serves to promote the values of federalism must take into account the constitutional mechanisms that shape state and federal power, as well as their judicial constructions. This Note addresses only the constitutional mechanisms invoked by the Patient Protection and Affordable Care Act. These include the Spending Clause Doctrine, Congress's power to tax, sovereign immunity, the Supremacy Clause, and the Commerce Clause.

Congress's Spending Clause power is found in Article 1, Section 8 of the U.S. Constitution. ${ }^{178}$ In this area, Congress's practice of conditional spending has the largest impact on the shape federalism. The Dole Doctrine, articulated in South Dakota v. Dole, ${ }^{179}$ lays out the constitutional standard that Congress must meet when it conditions the receipt of federal funds on the state's compliance with a national regulatory standard. ${ }^{180}$ In this case the Court upheld the constitutionality of a federal law that made federal highway funding contingent on the states' changing the drinking age to twenty-one years. ${ }^{181}$ The Court reasoned that the power to tax and spend for the general welfare could be used to obtain regulatory objectives not otherwise within Congress's plenary powers, but only where four standards are met. These standards are: (1) the spending must be for the general welfare; (2) the conditions attached must be unambiguous, or "cognizant of the consequences of their participation"; ${ }^{182}$ (3) the federal grants must be related to the federal interests involved; and (4) the condition attached must not run afoul of any other constitutional provision. ${ }^{183}$ There is also an auxiliary fifth prong, which is the recognition that "in some circumstances the financial inducement offered by Congress might be so coercive as to pass the point at which "pressure turns into compulsion.""184 This prong is used in the Florida proceedings to challenge the attachment of federal health services funding to the states' implementation of the Act's regulatory scheme. ${ }^{185}$ This claim was not dismissed, but the court noted "the current

177. See, e.g., The Federalist No. 40 (James Madison) (Saul K. Padover ed., 1953) (describing the need for a federal government with sufficient general powers to promote the general welfare, balanced with sovereign states).

178. U.S. ConsT. art. I, $\S 8$, cl. 1 .

179. South Dakota v. Dole, 483 U.S. 203 (1987).

180. Id. at 207-08.

181. Id. at 212.

182. Quoting Pennhurst State Sch. \& Hosp. v. Halderman, 451 U.S. 1, 17 (U.S. 1981).

183. Id. at 207-08.

184. Id. at 211 (quoting Steward Machine Co. v. Davis, 301 U.S. 548, 590 (1937)).

185. Order and Memorandum Opinion (Defendant's Motion to Dismiss), Florida ex. rel. McCollum v. U.S .Dep't of Health \& Human Servs., 716 F. Supp. 2d 1120, 1157 (N.D. Fla. 2010) (3:10-cv-91-RV/EMT). 
status of the law provides very little support for the plaintiffs' coercion theory argument."186 This outcome could be linked to the fact that the Court in Dole tempered its decision with the declaration that in adjudicating the constitutionality of conditional spending, federal courts should "defer substantially to the judgment of Congress." 187

Congress's power to tax originates in Article 1, Section 8 of the U.S. Constitution, which gives Congress the power to lay and collect taxes for the general welfare and common defense. ${ }^{188} \mathrm{~A}$ tax under this provision is defined as "a pecuniary burden laid upon individuals or property for the purpose of supporting government." 189 Under this provision a tax must be laid for the purposes of supporting government. However, Congress may also use the taxing power to enforce an exercise of an enumerated power by imposing a penalty. ${ }^{190}$ The Sixteenth Amendment gives Congress the power to raise an income tax. ${ }^{191}$ Together, these two provisions give Congress a monopoly over government sources of revenue.

Sovereign immunity is embodied in the Eleventh Amendment, which states that " $[\mathrm{t}]$ he Judicial power of the United States shall not be construed to extend to any suit in law or equity, commenced or prosecuted against one of the United States by Citizens of another State, or by Citizens or Subjects of any Foreign State."193 The conceptualization of sovereign immunity is complex and exists historically in a variety of permutations. ${ }^{194}$ In the context of the U.S. Constitution the concept is well summed up by the case of Seminole Tribe of Florida v. Florida, in which the Court stated: "The Eleventh Amendment presupposes that each State is a sovereign entity in our federal system and that 'it is inherent in the nature of sovereignty not to be amenable to the suit of an individual without a State's consent.",195 This

186. Id. at 1159 (citing Nevada v. Skinner, 884 F.2d 445, 448 (9th Cir.1989)) (explaining if the coercion theory stands at all, it stands on extremely "wobbly legs").

187. Dole, 483 U.S. at 207.

188. U.S. Const. art. I, §8, cl. 1.

189. United States v. Reorganized CF\&I Fabricators of Utah, Inc., 518 U.S. 213, 224 (1996) (quoting New Jersey v. Anderson, 203 U.S. 483, 492 (1906)) (stating the historical definition of a tax).

190. Sunshine Anthracite Coal Co. v. Adkins, 310 U.S. 381, 393 (1940) (holding that to pass constitutional muster, a penalty must be used to further a constitutionally enumerated power).

191. See, e.g., Lynn A. Baker, Conditional Federal Spending after Lopez, 95 ColuM. L. REV. 1911, 1936 (1993).

192. See, e.g., id. at 1938.

193. U.S. CONST. amend. XI.

194. See, e.g., Donald L. Dorenberg, SovereIGn IMMUNITY OR THE RULE OF LAW: THE NEW FEDERALISM's CHOICE (2005).

195. See Seminole Tribe of Florida v. Florida, 517 U.S. 44, 44 (1996) (quoting Puerto Rico Aqueduct \& Sewer Auth. v. Metcalf \& Eddy, Inc., 506 U.S. 139, 146 (1993)) (holding that the Eleventh Amendment not only protects the states from becoming party to law suits by judicial or congressional coercion, but also serves as "a recognition that the States, although a union, maintain certain attributes of sovereignty" within the constitutional system). 
concept is important because it has been used as a limit on federal power, and as a means to give state autonomy life in the text of the Constitution. For instance, the concept of sovereign immunity coupled with the Tenth Amendment's grant of police powers to the states, is used to give the states nearly complete autonomy over land use regulation and has hindered the passage of a federal land use statute since one was first introduced in 1972. ${ }^{196}$ This idea has also been used to overturn federal efforts to restrict the use of local land by state agencies. ${ }^{197}$ In these situations the Court is doing more than invalidating government action because it violates an express constitutional provision, it is implementing "constitutional values into behavioral norms that impact the nature of national-state interaction." ${ }^{.198}$ In this way, the court recognized that the Constitution's federalist structure regulates the interaction of the state and federal governments on expressive grounds.

Like the Eleventh Amendment, Article V can be construed to convey sovereignty to the states. As states must "consent" to be party to suit under the Eleventh Amendment, Article $\mathrm{V}$ requires that two-thirds of the states "consent" to any proposed constitutional amendment. ${ }^{199}$ Giving the states the ultimate check on the enumeration of additional federal power reflects the fact that the states existed before the federal government, and entered into the Constitution to transfer to it only those powers they saw necessary for the operation of an effective general government. This perspective is supported by the $10^{\text {th }}$ Amendment's reservation of all powers not expressly enumerated to the federal government to the states. Article $\mathrm{V}$ bolsters the validity of this perspective by giving the states ultimate control over the enumeration of new federal powers, which can only be accomplished by constitutional amendment.

The federal counterpart to sovereign immunity is found in Article VI, Clause 2, and is referred to as the Supremacy Clause. The Supremacy Clause invalidates state laws that conflict with legitimate federal laws. ${ }^{200}$ The practice of invalidating state law through passing conflicting federal law is referred to as preemption, and has become accepted as a sort of un-

196. John R. Nolan, et al., LAND USE AND COMmUNITY DEVELopment 114 (7th ed. 2004) (explaining also that federal influence over land regulation is still prevalent in the form of conditional spending).

197. Solid Waste Agency of Northern Cook County v. U.S. Army Corps of Eng'rs, 531 U.S. 159, 172-174 (2001) (striking down federal efforts to stop the construction of a landfill by local officials in Chicago based on federal concern for migratory birds).

198. Copeland, supra note 13, at 549 (interpreting Solid Waste Agency of N. Cook Co. v. U.S. Corps of Engineers, 531 U.S. 159 (2001), as limiting federal control of state land use practices on grounds that such 'behavior' violates federalist norms required by structural provisions of the constitution, and not because the activity exceeds federal authority under any one enumerated power).

199. U.S. CONST. art. V.

200. See U.S. ConST. art. VI, cl. 2. 
enumerated federal power. ${ }^{201}$ To say a state law is preempted means that federal law or regulation has taken away the state or local sovereign's authority to regulate in that area. ${ }^{202}$ As a general rule, "a federal statute preempts a state law where the latter 'stands as an obstacle to the accomplishment and execution of the full purposes and objectives of Congress." ${ }^{203}$ This is an extremely important concept in federalist jurisprudence because it gives express sovereignty to the federal government in the exercise of its enumerated powers, displacing state law where the sovereigns have concurrent authority.

Next is the Commerce Clause. Most relevant precedent on this subject was addressed in the section of this Note which outlined the state proceedings, and therefore the discussion here will be limited. ${ }^{204}$ The scope of the Commerce Clause was litigated time and again during the Twentieth Century, typically ending in an expansion of Congressional authority. ${ }^{205}$ Recent cases, however, have begun drawing the outer limits of Congressional power under the Commerce Clause. The case of United States $v$. Lopez outlines three areas that Congress may regulate under the Commerce Clause: (1) the use of the channels of interstate commerce; (2) the persons or things in interstate commerce; and (3) activities that substantially effect interstate commerce. $^{206}$ The earliest interpretations of Congress's Commerce Clause power defined the Tenth Amendment as stopping the federal government from preempting state regulation undertaken through the general police powers. ${ }^{207}$ However, the Court in United States v. Darby expressly rejected the idea that the $10^{\text {th }}$ Amendment places any affirmative

201. See, e.g., Cox, supra note 3, at 1344 (arguing that "tools like preemption and conditional grants are not perceived as expressing disrespect for our federal structure because those tools have a long tradition of established practice," even though they are not expressly enumerated).

202. Robert S. Peck, A Separation-of-Powers Defense of the "Presumption against Preemption," 84 TUL. L. REV. 1185, 1189 (2010).

203. See, e.g., Arizona v. Bowsher, 935 F.2d 332, 334 (D.C. Cir. 1991) (quoting Hines v. Davidowitz, 312 U.S. 52, 67 (1941)).

204. See supra note 79 (beginning this Note's conversation on Commerce Clause jurisprudence and citing several landmark cases).

205. See, e.g., Wickard v. Filburn, 317 U.S. 111, 124 (1942) (granting Congress the power under the Commerce Clause to regulate activities that have a 'substantial effect' on interstate commerce, even if the activity could not otherwise be defined as within the flow of commerce).

206. Diane McGimsey, The Commerce Clause and Federalism after Lopez and Morrison: The Case for Closing the Jurisdictional-Element Loophole, 90 CAL. L. REV. 1675, 1702 (2002) (citing United States v. Lopez, 514 U.S. 549, 575 (1995)).

207. See, e.g., United States v. E.C. Knight Co., 156 U.S. 1, 11-13 (1895) (invalidating efforts to regulate intrastate sugar production as a violation of the police powers left to the states and holding that "the power of a state to protect the lives, health, and property of its citizens, and to preserve good order and the public morals . . . is a power originally and always belonging to the states, not surrendered by them to the general government, nor directly restrained by the constitution"). 
limits on congressional authority. ${ }^{208}$

\section{A NEW APPROACH FOR FEDERALIST JURISPRUDENCE}

Current judicial efforts to protect federalism define specific limits on the enumerated powers of the federal government, but do not consider the values that these limits are intended to promote. ${ }^{209}$ A court may invalidate an aspect of Congressional legislation based on a syntactical threshold of substantive federal power, but in the same case uphold another provision that offends basic principles of federalism because it is within that syntax and because the court does not otherwise see state autonomy as a limit on enumerated powers. For instance, the court in the Florida proceedings found the individual mandate to be outside the realm of Congressional power under the Commerce Clause because the decision not to purchase health insurance is not an "economic activity." At the same time the court flatly rejected the commandeering claims against the Medicaid and American Health Benefit Exchange provisions because the requirements are within federal authority under existing jurisprudence, and because state regulatory sovereignty is not viewed as an affirmative limit on federal power. ${ }^{210}$ This sends the message that while federal power is limited, it is not limited by the need to promote the values of dual sovereignty, but by a textually contrived limit on Commerce Clause powers rooted primarily in semantics. At the same time it denies the constitutional value of state regulatory autonomy by allowing the federal government to compel state action or otherwise yield all regulatory relevance.

The courts should instead approach conflicts such as this one with a value driven rule. That is, the courts should look at how the contested action promotes or hinders the realization of values that underlie the federalist design of the constitution. This rule would better serve to protect the Constitution's structural requisites and their underlying purposes, by putting the onus of government action on the manner in which it promotes or hinders these values. This section will first explore the values of federalism and how they are manifest in constitutional structure. It will then outline the failure of the anti-commandeering rule to promote these values and describe how the rule could be applied more aptly to these ends.

208. H. Geoffrey Moulton, Jr., The Quixotic Search for a Judicially Enforceable Federalism, 83 MINN. L. REV. 849, 855 (1999) (citing United States v. Darby, 312 U.S. 100 (1941)).

209. See Cox, supra note 3, at 1348.

210. See generally Florida ex rel. Bondi v. United States Dep't. of Health \& Human Servs., 728 F. Supp. 2 d 768 (N.D. Fl. 2011). 


\section{A. Values of Federalism}

Adam B. Cox outlines three essential values of federalism: tyranny prevention, experimentation and efficiency, and the enhancement of democracy. ${ }^{211}$ Each value is transcribed through the structural provisions of the Constitution, which are built around three organizing principles: accountability, diversification, and checks. ${ }^{212}$ These principles are achieved through the Constitution's provision of dual sovereignty and divided power. If the corresponding structural provisions of the Constitution, discussed in the prior sections, are not applied in a manner that embodies these principles, the attached values of federalism cannot be achieved. Stated another way, if the states are not treated as regulatory sovereigns, then they cannot fulfill their role in the federal system, and the government cannot deliver the social and political values inherent to Constitutional order. ${ }^{213}$ The following paragraphs will define each value and outline how its realization depends on the regulatory sovereignty of the states.

Tyranny prevention refers to "the fact that the states can serve as and foster political counterweights to the incumbent powers within the federal government."214 Cox argues that the states can serve this role by offering "organizations that can support generalized opposition to the federal government."215 Further, Cox explains that the political institutions of state government serve as an "interest group" on behalf of the citizens. In Federalist No. 26, Alexander Hamilton states, "the State Legislatures . . . will constantly have their attention awake to the conduct of the national rulers, and will be ready enough, if any thing improper appears, to sound the alarm to the people, and not only to be the VOICE, but, if necessary the ARM of their discontent." ${ }^{216}$ Without the actual and perceived capacity of the states to serve as a counterbalance to the federal government the states are unlikely to fulfill this role. Further, if the citizens of the states do not perceive this capacity they will not see the value in using state political institutions to such ends. In this way, tyranny prevention relies on the states enjoying the degree of sovereignty necessary to effectively check federal authority.

Experimentation and efficiency refer to the value of having multiple,

211. Cox, supra note 3, at 1320-1327; see also, e.g., Elizabeth W. Leonard, Rhetorical Federalism: The Value of State-Based Dissent to Federal Health Reform, 39 HOFSTRA L. REV. 111 (2011) (arguing that the state initiated challenges are valuable in themselves regardless of their outcome because they bring federalist values and state rights into legal discourse).

212. Redish, supra note 13 , at 324.

213. Cox, supra note 3 , at 1316 ("[T] serving as alternative political institutions to the national government.").

214. Id. at 1324 .

215. Id.

216. Id. at 1324-25 (quoting THE FeDERALIST No. 26, at 217 (Alexander Hamilton) (Benjamin Fletcher Wright ed., 1996). 
independent regulatory entities and the "economic efficiency [realized] through competition among the states."217 The value of having multiple regulatory entities is in their ability to simultaneously undertake different approaches to the same problems; finding effective policy schemes through trial and error. This process also allows individuals to "vote with their feet." That is, where a state succeeds in crafting favorable policy and another state fails, the citizens of the latter state can move to the state with favorable policies, and in so doing show their support for one policy approach and their dislike for another. This process depends completely on the regulatory autonomy of the states to exercise the broad police powers left to them by the Tenth Amendment. ${ }^{218}$ It depends on the Court recognizing state autonomy as a limit on federal powers. When federal law is allowed to dictate regulatory details to the states, they are unable to implement creative policies, or adapt the administration of policy directives to local needs. It also prevents a state from making corrections to problems it observes in regulatory programs. Where the states are left in control of the regulatory details, they can respond to observed problems efficiently. This efficiency can foster public appreciation and respect for local government, potentially encouraging civic participation. The ability to respond to such failures with efficiency and speed also enhances democracy, which happens to be the next federalist value addressed in this Note.

Efficiency and experimentation also can refer to the benefit of giving the states the ability to take the lead on issues of concurrent jurisdiction where the federal government has failed. Recent budget measures in states like Wisconsin and Indiana are prime examples.

Finally, the states enhance democracy through local civic organizations and other means of democratic participation. They also enhance democracy by giving local citizens the ability to elect policy-makers that may represent their preferences better than the aggregate national government. In some ways, this enhancement of democracy relates to the value of competition. State citizens can elect new leaders when the policies of the previous leaders were not successful, and these new leaders can erect policies that better meet these preferences with relative expedience. This federalist benefit is also referred to as the 'fit' "between a given jurisdiction's policies and the preferences of local residents." ${ }^{219}$ The federal government does not give this same recourse. This is because if the federal government regulates

217. Id. at 1321; see also, e.g., Adler, supra note 135, at 204 (arguing that individual states create better policy through competition than the federal government can by independently implementing a single policy choice).

218. See, e.g., id. at 1324. The phrase "left to" the states by the Tenth Amendment, rather than "granted to" the states by the Tenth Amendment, is important because the Constitution does not grant legislative powers the states. The states are the source of the powers distributed by the Constitution, and interpreting the Constitution to grant substantive powers to the states would be intellectually self-defeating to the underlying concept of government.

219. Adler, supra note 135, at 202. 
an activity, and the citizens of some states are satisfied while others are not, only one of these preferences can be manifest in election results, thus leaving one set of citizens happy and the other not. If the states are left free to regulate the area, then a variety of political cultures can be represented in the policies of the several states, allowing individuals to choose the state that best represents their own political values.

The enhancement of democracy value depends on the states being given the requisite regulatory autonomy to create diverse policy. ${ }^{220}$ It also depends on the sovereign most accountable to its constituency holding the most regulatory authority. In other words, it requires the states to hold the most regulatory power over the citizens, as the citizens may more easily influence state policy to meet their interests. Similarly, enhanced democracy relates to the states capacity to make large-scale changes quickly as constituents demand, which is only possible through a grant of broad regulatory autonomy.

\section{B. An 'Expressive' Application of the Anti-Commandeering Rule}

As applied, the anti-commandeering rule does not adequately promote the values of federalism. ${ }^{221}$ The decisions in New York and Printz leave Congress free to impose uniform national regulation by preempting state law, or using a "carrot or stick" approach to coerce states into administering federal regulatory schemes. ${ }^{222}$ In turn, federalist values like experimentation are hampered by the inability of the states to implement their own policy schemes. They are further damaged by the perception of state political illegitimacy created by federal control of state regulation, and judicial support for this conduct. Adam B. Cox explains: "The capacity of a state government to act as a political counterweight to the federal government through intergovernmental checking depends on both national political actors and state citizens perceiving the state to be a credible political institution." 223 Cox further explains that a state's credibility depends on the state being able

to maintain legitimately that it represents the interests of its citizens and, as a corollary, to maintain legiti-

220. Id. at 202-203 (arguing that there is no single answer to health policy issues and the best results come from a decentralized system, in which the states are left to make policy that meets the preferences of their respective citizens).

221. Id.

222. Cox, supra note 3, at 1322-23 (referencing New York v. United States, 505 U.S. 144 (1992) (explaining that the anti-commandeering rule does not stop Congress from preempting state law, and does not apply where the challenged federal law was of general applicability); Printz v. United States, 521 U.S. 898, 918 (1997) (leaving intact Congress's conditional spending power)).

223. Cox, supra note 3, 1327. 
mately that it voice (or threats, as it may be) in the national political arena is backed by the political force of its citizen-constituents. This requires the state to be able to claim to both national political actors and its own citizens that it represents its citizens' preferences or best interests. $^{224}$

It is impossible for the states to be "credible political institutions" when judicial standards leave the federal government to exert control over state regulatory infrastructure and use the threat of monetary drawbacks to force states to undertake the administration of this regulatory scheme.

In turn, the anti-commandeering rule should be applied in a manner that articulates the values promoted by the federalist design of the constitution. This will better gauge the constitutionality of government action than setting thresholds on Congress's enumerated powers. Specifically, the anticommandeering rule should "invalidate congressional legislation that treats the states as puppets."225 That is to say, commandeering should be defined not just as a limit on Congress's ability to force states to pass certain laws, but also as a limit on Congress's ability to use its enumerated powers to coerce the states into acting as administrators of federal law. This rule would not invalidate generally applicable federal law, administered and enforced by the federal government. Congress could still directly regulate an industry under the Commerce Clause, for instance, so long as it did not require the states to enforce its laws through specific regulatory programs. That is, federal law would still preempt state law under the Supremacy Clause, but Congress could not force the states to implement specific regulatory schemes or outlaw similar state programs that are not inconsistent with the new federal law. This would fulfill the value of inter-state competition by allowing existing state programs to continue, while also promoting the federalist value of a strong general government. Congress would be left free to set general regulatory priorities on issues of national import, while the states would be left free to implement those priorities in an efficient manner that best represents the preferences of its constituencies.

Where deemed appropriate, Congress could establish federal programs that redirect federal funding from similar state programs or state administered federal programs, so long as they are fully administered by the federal government. Where state programs are preempted or otherwise made uncompetitive by the new federal scheme, the states could enter agreements with the federal government to participate in such programs, volunteering a portion of state resources and regulatory infrastructure to gain local administration of the federal program. Congress could not, however, make laws 
which require states to establish and administer a specific regulatory scheme, and provide that failure to comply with that requirement will result in a loss of federal funding and the assumption of all related regulatory burdens by the federal government.

With regards to this restriction on Congressional lawmaking, it is important to note that it is unlikely that the federal government actually has the political or logistical capacity to implement most nation-wide federal programs (e.g., Medicaid) without extensive state participation. To compensate for the lack of regulatory capacity, Congress often passes laws which require states to administer the resulting regulatory scheme or to lose access to related federal funds and all political relevance in the regulated area. ${ }^{226}$ Because state governments do not want to deprive constituents of important services offered through state administered federal programs, they accept the funds along with the attached conditions. ${ }^{227}$ Under an expressive jurisprudence, Congress would not be allowed to use its spending power in this way. As discussed above, constitutional governance requires that the states serve as legitimate political counterbalances to the federal government. ${ }^{228}$ Where the courts allow Congress to pass laws that put the states in the position of a bureaucratic agent or unruly dependent, it sends the message that the political structures of state government exist to serve federal priorities. ${ }^{229}$ Further, if Congress is prohibited from passing laws which assume and even detail state participation, and use Congress's greater access to tax revenue as the carrot and stick for state obedience, then Congress would have to pass laws which account for the specific regulatory capacity of the federal government, and which are politically popular enough to garner the support of state leaders. In turn, Congress would produce better public policy under an expressive federalist jurisprudence, because under an expressive theory Congress would not pass a law without first considering whether the federal government has the capacity to carry out the resulting regulatory scheme independently, or without otherwise ensuring that the law has sufficient political support to garner voluntary state cooperation.

Congress would not necessarily sacrifice substantive lawmaking powers under the expressive reading of the constitution outlined in this Note. Under an expressive view of federalist jurisprudence Congress could pass nearly all the substantive regulations in the Patient Protection and Afforda-

226. See, e.g., Second Amended Complaint, supra note 69, at $939-41,68,73$ (outlining state participation in the Medicaid program, and the consequences of the state withdrawing from participation).

227. Id. $\mid 68$.

228. See, e.g., infra note 201-203 (citing Cox, supra note 3, at 1324) (discussing the states' role as counterbalances to the federal government and the need to recognize state sovereignty to empower the states to fill this role).

229. See, e.g., Cox, supra note 3, at 1324-1325. 
ble Care Act. Congress could not, however, use the Act to place the states in a subservient position to the federal government, by requiring them to establish and administer a specific regulatory scheme, and to sacrifice critical federal funding or otherwise implement specific changes to state Medicaid programs that essentially eliminate the ability of the states to operate the federal program in a manner that accounts for local preferences and individual circumstances. ${ }^{230}$ How the expressive rule specifically applies to the Patient Protection and Affordable Care Act will be addressed more thoroughly in the following section.

\section{ANALYSIS}

This section will apply the expressive rule discussed here to different provisions of the Patient Protection and Affordable Care Act. The outcomes will demonstrate how expressive principles can be used to draw thresholds on federal power that do not depend on epidemiological inquiry into the precise words of the enumerated power exercised. Applying a legal test based on "values" always runs the risk of political bias. The rule presented here is strictly based on federalist concepts of state and federal power underlying the text of the Constitution. It uses a holistic reading of that text to draw a picture of the resulting form of government and to decipher the political values enforced by that form of government. The first example will demonstrate how an expressive federalism would not necessarily enhance the power of the states, or limit the regulatory sovereignty of Congress, but rather would limit the ability of Congress to use its enumerated powers in a way that ignores and detracts from state regulatory autonomy. As will be shown, Congress would still have the power to regulate areas it currently regulates, but Congress could not create policy based on using the states as administrative agents.

Provisions of the Patient Protection and Affordable Care Act that introduce direct federal regulation into intrastate insurance industries would be found constitutional under an expressive theory of federalism. Contrary to traditional views, ${ }^{231}$ the federal government has the power to regulate the insurance industry. ${ }^{232}$ Hal S. Scott explains that insurance companies are now largely owned and operated by nation-wide financial companies and in

230. See Second Amended Complaint, supra note 69, \ 53-60 (outlining the regulatory burdens placed on the states through the Act, and explaining how these burdens, along with the Act's Medicaid reforms, restrict the states' ability to regulate insurance and administer related health service programs in a manner that accounts for local demographics, and the need for state government to address other priorities).

231. See, e.g., McCarran-Ferguson Act, 15 U.S.C. $\$ 1011$ (2011) (limiting Congress's regulation of the insurance industry by protecting state insurance regulation from federal preemption).

232. See Adler, supra note 135, at 207 (arguing that Congress has "ample power to regulate health care and health insurance markets"). 
turn integrated into an industry currently under the auspices of federal control. $^{233}$ Further, current limits on federal regulation of insurance are statutory, not constitutional, and the McCarran-Ferguson Act allows federal law to preempt conflicting state insurance law where the federal law "specifically relates to the business of insurance.",234 Under the McCarran-Ferguson regime, insurance transactions have been artificially confined to intrastate markets, as each state was left to create separate rules and regulations governing the sale of insurance policies. Where access to insurance markets is restricted by the multifariousness of state-level regulation, the passage of federal law to remove these barriers to market entry should be deemed an appropriate exercise of Congress's preemptive authority under the Commerce Clause.

This regulatory authority could be extended to establish the minimum health benefits an insurance policy may offer as a condition on participation in the industry. Such regulatory efforts would fit within Congress's authority to establish laws necessary and proper for the execution of a plenary power, in this case the regulation of interstate commerce. ${ }^{235}$ Congress's $^{2}$ commerce power includes the authority to "facilitate interstate commerce by eliminating potential obstructions, and to restrict it by eliminating potential stimulants." ${ }^{236}$ In this vein, the federal government makes a convincing argument that "decisions about how to pay for health care in the aggregate shift tens of billions of dollars of health care costs each year, from the uninsured, who frequently are unable to pay for the medical services they receive, onto other participants in the health care market."237 If insurance companies are forced to sell a minimum set of benefits for a reasonable rate it would encourage participation in insurance markets and decrease the number of uninsured. In turn, such rules would be "appropriate" and "plainly adapted" to executing Commerce Clause power. ${ }^{238}$ Along this same line of reasoning, Congress's Commerce Clause power extends to the Act's effort to make insurance markets more accessible by prohibiting in-

233. Scott, supra note 6, at 139.

234. 15 U.S.C. § 1012(b) (2011); see, e.g., Pallozi v. Allstate Life Ins. Co., 198 F3d 28 (1999) (applying 1012(b) to uphold federal regulation of the underwriting practices of insurance companies).

235. See, e.g., Gonzales v. Raich, 545 U.S. 1, 34 (2005) (arguing that Congress may use the Necessary and Proper clause to regulate non-commercial activities to ensure the success of larger regulatory schemes carried out under the Commerce Clause).

236. Id. at 35 (citing NLRB v. Jones \& Laughlin Steel Corp., 301 U.S. 1, 36-37 (1937) (defining two circumstances where regulation of interstate commerce may be necessary and proper)).

237. Reply in Support of Defendant's Motion for Summary Judgment at 7, Florida ex rel. McCollum v. U.S. Dept't of Health \& Human Servs., 780 F. Supp. 2d 1256 (N.D. Fla. 2011).

238. Gonzales v. Raich, 545 U.S. 1, 60 (2005) (Scalia, J., concurring) (stating that an exercise of the Necessary and Proper clause is valid where "Congress [selects a means of regulation] that is 'appropriate' and 'plainly adapted' to executing an enumerated power"). 
surers from denying coverage or setting premium prices based on an applicant's pre-existing condition. This removes further obstacles from entry into insurance markets. The reforms guarantee that individuals who cannot access coverage under the current system will be able to purchase insurance in every state market at a reasonable price. Congress's power to regulate underwriting practices is supported by Pallozi v. Allstate Life Insurance Co., where the court upheld provisions of the Americans with Disabilities Act that prohibited insurers from denying applicants based on a disability. ${ }^{239}$

These industry regulations promote the federalist value of a strong general government fit to pursue the general welfare of the people. Where a problem has national implications which cannot be appropriately resolved by the independent regulatory efforts of the states, the need for a strong national government is greatest, and federal action is most valuable. Health care is an issue that has taken on an ever-greater national dimension. Medicaid has grown significantly and has an important presence in every state insurance market. ${ }^{240}$ Medicaid funding is shared by every state and of course derived from the taxes paid by the citizens of each state. The more money hospitals lose rendering uncompensated and undercompensated care to the uninsured and indigent, the more health care costs will rise. Since health care costs are shared nationally, both through federal insurance programs and the multi-state operations of insurers, it is reasonable to look for a national solution. The Act's industry regulations that are geared toward opening insurance markets are therefore in line with the critical purpose citied by James Madison for abandoning the Articles of Confederation in favor of creating a federal constitution defined by a strong central government endowed with powers "adequate to the exigencies of government and the preservation of the union."241 The nature of regulable subject matter within Congress's Article 1, Section 8 powers, is likewise limited to activities that inherently entail issues of national import, and which cannot be effectively addressed by the legislative efforts of the several states. ${ }^{242}$ To conclude, an expressive theory of law would endorse Congress's efforts to address the national problems of uninsurance and rising health care costs by using its Article 1, Section 8 powers to make intrastate insurance markets accessible to all state citizens. However, the resulting laws would have to be administered by the federal government, and would still need the support

239. Pallozi v. Allstate Life Ins. Co., 198 F3d 28 (2d Cir. 1999).

240. See, e.g., Second Amended Complaint, supra note 69, ๆ 51 (outlining the effect of the Medicaid program on Florida's health insurance market and explaining that "even before passage of the Act, the Medicaid program imposed a heavy cost on Florida, consuming 26 percent of its annual budget. For fiscal year 2009-2010 alone, Florida [spent] more than $\$ 18$ billion on Medicaid, servicing more than 2.7 million persons.").

241. FEDERALIST No. 40, at 102 (James Madison) (Saul K. Padover ed., 1953).

242. See generally Cooter, supra note 157. 
of the people to remain in force. ${ }^{243}$ This latter observation will be expanded on later.

Unlike the Act's general regulation of the insurance industry, the individual mandate provision would be held invalid under an expressive view of federalism. Since the states have sovereign authority over the exercise of all powers not enumerated to the federal government, any expansion of those enumerated powers necessarily means a contraction of state sovereignty. ${ }^{244}$ Since the individual mandate exceeds Congress's Commerce Clause power, or at least expands its scope to allow for the regulation of decisions not to enter interstate commerce, its validation would represent an expansion of federal authority. ${ }^{245}$ By expanding the scope of the Commerce Clause, the courts would allow Congress to regulate any number of activities or passive decisions so long as they have a substantial impact on national commerce. Allowing Congress to regulate beyond the scope of its textual power detracts from the states' ability to check federal power by using the courts to enforce the textual bounds of the Constitution. This is offensive to tyranny prevention. It is also offensive to the values of efficiency and experimentation. Allowing Congress to regulate new types of activities under the Commerce Clause infringes on the Tenth Amendment's reservation of state sovereignty over such activities. This means there are fewer circumstances in which the states can adopt independent policy measures, and facilitate competition among these approaches. It also means the states are less able to make policy that meets the preferences of their individual constituents, and the people are in turn less able to affect policy preferences using the state political process. ${ }^{246}$

As an alternative to the mandate, Congress could establish a singlepayer insurance system in which every individual pays a tax and in turn receives health benefits from the federal government. Since Congress can regulate insurance under the Commerce Clause, and since there is no forced purchase, the single payer system would not violate or expand Congress's enumerated powers. The states would not be commandeered to implement individual insurance exchanges, and the people would not be forced to undertake a commercial activity involuntarily (although their choice in regards to the purchase of health insurance would be obliterated). Under the tax

243. See generally Cox, supra note 3 , at 1326 (arguing that federalism prohibits federal law that treats the states as administrative puppets, and argues that where the people perceive their state government as ineffective to protect their political interests, they will participate directly in the political process rather than the state).

244. U.S. CoNST. amend. X.

245. Memorandum Opinion (Cross Motions for Summary Judgment), 728 F. Supp. 2d 768, 782 (E.D. Va. 2010) (concluding that the decision not to purchase insurance is not a commercial "activity" regulated under existing understandings of the Commerce Clause).

246. Adler, supra note 135, at 202 (arguing that the federal government should not pass legislation that attempts to offer a "single right answer" to a problem that evokes a variety of policy preferences). 
and spend power, Congress could institute a tax on every individual and use it to fund a federal health plan. In this way, much like social security, holding a health insurance plan would simply be a product of paying taxes. While this approach appears to be a greater exertion of federal control then the regulatory scheme established by the Act, and would not be attractive to an advocate of small government or individual economic freedom, it does not violate the constitution's political order, nor the values underlying a well-enforced federalist government. A federal single payer system would simply replace the Act's state-exchange system with a single federal exchange, which would assume the full administrative burden for distributing government insurance policies. This would fulfill the value of a strong general government, capable of instituting unitary solutions to national problems. While it would contradict the value of experimentation, it would further the value of efficiency, as in instances of national necessity a single policy answer is preferable to multiple state approaches.

This conclusion is not an endorsement of a single-payer system. Congress could create such a regulatory regime, but will only do so if it has the political capital to do so. Herein lies one of the most important checks on the federal government-the political process. Elections give the people the ultimate check on Congress's ability, and willingness, to regulate. State sovereignty only prevents the federal government from exceeding its plenary powers, and cannot check independent federal regulation of activities within those plenary powers. It is ultimately up to the people to use the political process to decide which activities the federal government will regulate with its enumerated powers. It is that much more important, therefore, that the courts enforce state sovereignty and restrict the manner in which the federal government regulates. Otherwise the people's check on the activities regulated by Congress will not be reinforced by constitutional limits on Congress's regulatory authority.

The Act's requirement that states establish an American Health Benefit Exchange would be invalidated under a value-centered theory of federalism. This requirement damages the political legitimacy of the states and treats them as "puppets." 247 Further, it hinders the value of competition by dictating to the states how to regulate intrastate insurance transactions. Dictating regulatory process also limits the states' ability to respond to the preferences of their constituents. Where Congress at once preempts state regulation and simultaneously requires the states to enforce the corresponding reforms, Congress furthers the value of having strong central government, but violates the constitutional autonomy of the states. The Act does offer the opportunity for the states to apply for a waiver of its provisions. ${ }^{248}$

247. See Cox, supra note 3, at 1330-31; see also New York v. United States, 505 US 144, 188 (1992).

248. Patient Protection and Affordable Care Act $\S 1332,42$ U.S.C $\S 18052$ (2011). 
However, the waiver requires that the state regulatory plan include the establishment of an exchange under the definition of the Act. ${ }^{24}$ It requires coverage offered through such an exchange to meet the requirements of the essential benefits package. ${ }^{250}$ The waiver provisions do not allow the states to retain regulatory autonomy. Ultimately, the states may opt out of the exchange requirement and allow the federal government to assume the Act's full regulatory burden on the state's behalf. ${ }^{251}$ Congress probably assumes that this option will scarcely be exercised. If every state opted out of participation and instead left the Act's full regulatory burden to the federal government, it is unlikely the Act's provisions could ever be fully implemented. ${ }^{252}$

The exchange provision is also important for its expressive implications on federalism. By allowing Congress to treat the states as "administrative agencies" of the federal government, the court sends the message that the states are not counterbalances, nor political alternatives to the federal government, but rather its administrative arms. ${ }^{253}$ This gives the people the perception that the states are not viable means to further their interests and discourages state-level participation. This of course impacts the ability of the states to facilitate the collective rebuke of federal policy. ${ }^{254}$ Both of these outcomes harm the values of tyranny prevention and the enhancement of democracy.

As for the commandeering claims related to Medicaid, ${ }^{255}$ the most harmful provisions for the values of federalism are those that dictate how the states can administer the Medicaid program. ${ }^{256}$ This harms the value of competition by limiting state flexibility to administer the Medicaid program in different ways, thereby finding the best policies by trial and error. Further, it destroys the ability of individuals to choose the state that best meets their policy preferences. This is not to say that Congress cannot set minimum standards for state Medicaid programs, but only that these standards should not reach the point where they compromise the role of the states in the federalist balance of power. ${ }^{257}$

249. Id.

250. Id.

251. Patient Protection and Affordable Care Act $\S 1321,42$ U.S.C. $\S 18041$ (2011).

252. See, e.g., Second Amended Complaint, supra note 69, I 53-60 (explaining the regulatory burden placed on the states by the Act and the difficulties posed to state implementation). The fact that state governments with established regulatory infrastructures are struggling to implement the Act's regulatory program for their individual jurisdictions, raises questions as to how the federal government would be able to implement that program from scratch for all 50 state jurisdictions.

253. New York v. United States, 505 U.S. 144, 188 (1992) (arguing that Congress cannot force states to adopt federal regulatory programs).

254. Cox, supra note 3, at 1324-1325.

255. See Second Amended Complaint, supra note 69, ๆ 83-86.

256. See The Patient Protection and Affordable Care Act, $\S 2001,42$ U.S.C. 1396a.

257. See Adler, supra note 135, at 208 (citing Gonzales v. Oregon 546 U.S. 243, 271 
This threshold is breached where federal control over state administration preempts all state efforts to account for local circumstances in operating the program. As mentioned above, the Patient Protection and Affordable Care Act curtails state efforts to keep the costs of Medicaid down by prohibiting restrictions on eligibility and requiring states to provide Medicaid participants with an extensive set of health benefits. ${ }^{258}$ It further eliminates state discretion in how the program is administered by putting in place comprehensive instructions for how the Medicaid program is to be operated and presented to citizens. ${ }^{259}$ Where, as with Medicaid, the states enter into a regulatory "partnership" with the federal government, through which services are provided to citizens that neither the states nor federal government could alone offer, the sovereignty of the states should be enough to invalidate federal legislative efforts to transform the regulatory partnership into a set of federal dictates carried out by quietly compliant state governments. When the states lose all regulatory discretion, and assume the role of passive administrators, the federal-state partnership ceases to further the value of state participation in the program. ${ }^{260}$ As such, Congress should either allow the states to administer Medicaid in a way that acknowledges state autonomy, or else assume complete control of administering the program.

By threatening to take away Medicaid funding from states that do not comply with the reforms discussed above, the Act again compromises the political legitimacy of the states. It does so by hindering the states' ability to create policy that satisfies the needs of constituents. Federal funding for Medicaid makes up a large portion of the funds spent by states to provide health care to the indigent and elderly. ${ }^{261}$ Some scholars argue that Medicaid has evolved into a de facto "obligatory" program for the states to operate, because it so important to their citizens. ${ }^{262}$ Because the federal government has access to more revenue through its general taxing power

(2006) (explaining that Congress may set "uniform national standards" in the area of health care but commandeering state policy in this area is "off the table")).

258. See Patient Protection and Affordable Care Act $\S 2702,42$ U.S.C. $\S 300 \mathrm{gg}-1$ (a)(1) (2010); Second Amended Complaint, supra note 69, at $\$ 52-54$ (explaining the impact of new eligibility requirements on state capacity to administer Medicaid).

259. See generally Patient Protection and Affordable Care Act, $\S 1943(\mathrm{~b})(\mathrm{a})(\mathrm{A}), 42$ U.S.C. § 1396w-3(b)(1)(A) (2011); § 1943(b)(a)(A), 42 U.S.C. § 1396w-3(b)(1)(A); § 1302, 42 U.S.C. $\S 18022$ (requiring Secretary to establish standards for essential benefits plan required for Medicaid policies); § 2002, 42 U.S.C. 1396a(e)(14).

260. See, e.g., Patient Protection and Affordable Care Act $\S 1311,42$ U.S.C. $\S$ 18031(d)(4)(B) (2011) (requiring the states to create a phone line citizens can call for information about insurance provided by the state-exchange). This provision restricts the state's ability to administer the Act's underlying program in a manner that best responds to local needs.

261. Memorandum in Support of Plaintiff's Motion for Summary Judgment, supra note 123, at 44 (arguing that state residents would lose out on health benefit programs if federal funding stopped).

262. Adler, supra note 135 , at 215 (citing the argument that "Medicaid has a political 'lock-in effect' that limits the ability of states to opt out of the program"). 
and nation-wide tax base, it is an abuse of this power to use it to coerce states to comply with federal dictates, particularly where the funding is directed toward such an important program. This is especially so since the states granted Congress its monopoly over tax revenue through their ratification of the Sixteenth Amendment, which they most likely would not have done with the expectation that Congress would use the resulting revenue to further impinge on state legislative autonomy. ${ }^{263}$

Beyond these expressive limitations, Congress's spending power is textually limited to providing for the national defense and general welfare. Where a state is denied access to federal health service funding based on its failure to administer the Medicaid program to exact federal specifications, Congress is not using its spending power to promote the "general welfare" because needy citizens of the de-funded state would be denied access to federal benefits enjoyed by similarly situated citizens domiciled in compliant states. With conditional spending, Congress can never promote the general welfare because the spending will only promote the welfare of citizens residing in compliant states. As for the states, Congress's use of its spending power to dictate federal priorities into state law does not promote the "general welfare" of the nation. While the specific dollars may ultimately promote the general welfare of state citizens, the use of the spending power initially as a pivot for leveraging federal policy preferences against state regulatory autonomy in fact detracts from the general welfare by hindering the realization of political values attributable to the proper operation of federalist government. However, conditioning the receipt of federal funds on the states' use of those funds to implement a general regulatory scheme aimed toward providing state citizens with needed services may be constitutionally acceptable. Requiring states to use federal funds to provide a service to its citizens promotes the general welfare. But in all circumstances, the amount of funds distributed by Congress to an individual state should be determined by state population or relative programmatic need, and not the degree to which the state implements specific, non-substantive federal dictates. In this way, Congress can address a national issue that individual states cannot afford to deal with alone by providing states with the requisite funds and a regulatory roadmap. This promotes the value of a strong central government while leaving state autonomy intact. From an expressive perspective, this type of federal funding regime would appropriately portray Congress's superior capacity to address national issues, and also further the concept of a cooperative federalism, in which mutual respect for the sovereignty of the states and the federal government is constitutionally enforced.

263. Baker, supra note 191, at 212-14 (explaining that the states gave Congress their monopoly on revenue voluntarily through the ratification of the 16th Amendment, and it is used to impinge on state autonomy). 
To conclude, the Constitution's textual limitations on Congress's spending power fulfill the federalist purpose of creating a strong central government particularly suited to act on issues of national importance. Congress's power to act is deliberately tailored to national issues, specifically the national defense and general welfare. With this in mind, the courts' endorsement of the modern conditional spending regime appears intellectually irreconcilable with the spending power's text and the federalist principles it furthers. A common justification used to ignore such federalist directives in the text of the Constitution, is that over time the states have granted the federal government the authority it currently wields, and have consented to their diminished role in the political order. Conditional spending is one example of this phenomenon, as scholars argue that when the states agreed to take federal funds they consented to meet any regulatory conditions Congress might attach to those funds. $\mathrm{T}$ his argument will be addressed in the following section.

\section{AN IMPORTANT COUNTERARGUMENT}

One may argue that the states have consented to the expansion of federal power discussed in this Note, and in turn knowingly sacrificed their regulatory autonomy. ${ }^{264}$ Specifically, Article $\mathrm{V}$ gives states the ultimate control over the fate of constitutional amendments. ${ }^{265}$ By ratifying the Sixteenth Amendment, the states voluntarily created a federal monopoly over tax revenue. ${ }^{266}$ The states have further tied their own hands by restricting their tax power in state constitutions. ${ }^{267}$ Through these actions, it can be argued that the states have voluntarily submitted themselves to conditional spending by the federal government, and in turn given up their expectation of regulatory autonomy. ${ }^{268}$ If the states tie their own hands in terms of revenue generation, they cannot reasonably expect to regulate completely independent of federal handouts. And in turn, the federal government cannot be expected to make monetary grants to the states for no consideration. ${ }^{269}$

264. See Michael B. Rappaport, Reconciling Textualism and Federalism: The Proper Textual Basis of the Supreme Court's Tenth and Eleventh Amendment Decisions, 93 Nw. U. L. REV. 819, 864 (1999) (arguing that amendments have created a new constitutional order that reflects new risks to state sovereignty).

265. U.S. CoNST. art. V.

266. Baker, supra note 191, at 214 (citing Lino A. Graglia, From Federal Union to National Monolith: Mileposts in the Demise of American Federalism, 16 HARV. J.L. \& PUB. POL'Y 129, 130-31 (1993)) (arguing that the states voluntarily gave the federal government a monopoly on tax revenue and this has been used to further diminish their regulatory autonomy).

267. Id. at 212 (citing a few examples of state's limiting their taxing power by constitutional amendment).

268. Id. at 212-218 (outlining the practice of conditional spending and its implications on state regulatory sovereignty).

269. Id. at 212 (explaining that the states must submit to federal regulations in order to 
Giving up access to revenue is thus defined as constructive consent to federal control of state lawmaking.

Likewise, the states sacrificed a portion of their political sovereignty by ratifying the Seventeenth Amendment thus leaving the election of Senators to the people. ${ }^{270}$ Without the ability to elect Senators, it is argued that states cannot adequately protect themselves from coercive exercises of federal power. ${ }^{271}$ In this way, it is argued that by consenting to give up control over the election of Senators, the states voluntarily submitted to the regulatory control of the federal government. This interpretation of the $17^{\text {th }}$ Amendment's effect does not consider the context in which it was drafted, or the constitutional values underlying the states' decision to ratify. In fact, the amendment was not a means to weaken states, but to decrease the time it takes to elect Senators and eliminate corruption linked to the states' selection of senators. ${ }^{272}$ These two purposes promote the federalist values of enhanced democracy and prevention of tyranny. Democracy is enhanced by giving the people the choice of their representatives, while the prevention of tyranny is promoted by eliminating corruption and also by removing a state control over the make-up of the federal government, thus fostering a more cooperative dual federalism. In this context it is hard to say that the Seventeenth Amendment should be construed as a limit on state sovereignty, as the transfer of power made by the states served the purpose of promoting inherent federalist values. Even with the Seventeenth Amendment the states still maintain some constitutional control over the shape of the federal government through the electoral college established under Article I, Section 1, Clause 2, and the Article I, Section 4, Clause 1 power of the state legislatures to set the time, place, and manner for holding Congressional elections. $^{273}$ Further, state governors must approve Senate judicial appointments, giving the political apparatus of the state continued supervision of Congressional activity which has a direct effect on the formation and operation of state law.

Returning to the Sixteenth Amendment, while the states undoubtedly consented to the transfer of taxing power to the federal government, this transfer of power cannot be expanded beyond those police powers the states expected to sacrifice in ratifying the amendment. Nor can it be construed to reset the constitutional order created by the document's remaining provisions. That is, this single transfer of power cannot be construed to com-

receive funds, and where they do not like the federal policy they must decide whether to enforce the policy and take the money, or decline to enforce the policy and lose the attached funds).

270. Rappaport, supra note 264 , at 866 (explaining that the federalist dynamic has changed with the ratification of the Seventeenth Amendment).

271. Id. at 866 .

272. Vikram David Amar, Indirect Effects of Direct Election: A Structural Examination of the Seventeenth Amendment, 49 VAND. L. REV. 1347, 1353 (1996).

273. See U.S. ConST. art. II, § 1, cl. 2; U.S. ConST. art 1, § 4, cl. 1. 
pletely reframe the institutional design of the Constitution. ${ }^{274}$ This is especially true since the amendment was passed in 1913 at a time when nowhere near the degree of government regulation existed as exists today. The functions served by state government in 1913 did not require the level of funding needed for state-provided services now considered to be essential. Nor did the states expect the federal government to assume the regulatory role it serves today. In fact, at that time the Supreme Court considered the states to have tax immunity, and held that states could not be made to enforce federal law. ${ }^{275}$ In turn, it is not reasonable to assume that when the Sixteenth Amendment was ratified, the states expected to sacrifice accesses to needed tax revenue, or to make themselves dependent on federal funding for regulatory activities they had not yet imagined. To argue otherwise requires the transposal of modern political circumstances onto decisions made by states governments ninety-eight years ago.

In conclusion, consent justifications for increased federal control must be limited by an examination of the constitutional context in which the states' transfer of power was made, the reasons it was made, and the effect of the new amendment within the resulting constitutional order. Where the states sacrificed a power to promote a federalist value, or at a time when the sacrifice of that power had a limited effect on its sovereignty due to existing legal conditions, it should not be assumed that the ratification of the amendment conferred the states' consent to serve a lesser role within the constitutional order. The argument that the states consented to serving a lesser role in the modern political order cannot be justified by reference to their ratification of amendments ninety-eight years ago, at a time when the federal government's exercise of such powers did not pose a threat to state sovereignty.

\section{SUMMARY}

The Patient Protection and Affordable Care Act expands the role of the federal government in the regulation of health care. The Act establishes a regulatory scheme and gives the states a Hobson's choice to enforce its provisions or to sacrifice their participation in the regulation of health insurance. However, current federalist jurisprudence is inadequate to promote the values that underlie constitutional order. In particular, the anticommandeering rule does not accomplish its stated purpose to protect the regulatory autonomy of the states and prevent the federal government from

274. Rappaport, supra note 264, at $866-867$ (arguing that it is possible to find immunities for states against conditional spending and commandeering even with the Sixteenth and Seventeenth Amendments).

275. Id. at 866 n.150 (1999) (citing Collector v. Day, 78 U.S. 113 (1870) (holding that states were tax immune); Kentucky v. Dennison, 65 U.S. 66 (1860) (holding that states could not be compelled to enforce federal law)). 
treating the states like administrative puppets. In order to maintain the form of federalist government required by the constitution, the anticommandeering rule must be applied in a manner that treats the states as independent sovereigns. This can be accomplished by framing the threshold of constitutional validity for a given exercise of federal authority, as the manner in which the action furthers the political values the constitution's federalist structure was created to promote. Where federal regulatory efforts disregard the sovereignty of the states and hinder their ability to act as viable political alternatives to federal authority, the corresponding law may be unconstitutional if it does not otherwise promote a value inherent to the federalist structure of constitutional governance. The value of a strong general government capable of addressing national issues, for example, will outweigh the loss of other federalist values where Congress assumes regulatory control over an activity within the reach of its enumerated powers but previously regulated by the states, so long as it does not unduly infringe on state sovereignty in the process.

Without a strong judicial rule to protect regulatory sovereignty, states have little recourse to federal action. They depend instead on federal political institutions to create changes on behalf of constituents. This is not an efficient form of recourse, nor does it fulfill the states' role in tyranny prevention. The proceedings against the Patient Protection and Affordable Care Act give the courts the opportunity to establish such a rule. The States cite federalist arguments in support of their commandeering claims, ${ }^{276}$ as wells as in support of their arguments against the individual mandate. ${ }^{277}$ While the courts have acknowledged this position, each ultimately declined to use federalist principles as dispositive factors in determining the constitutionality of the federal law. ${ }^{278}$ Even though the Florida district court found the entire Act void, this was based solely on its finding that the individual mandate is unconstitutional and non-severable from the reaming provisions. The Act's challenged Medicaid reforms and programmatic mandates were found constitutional by the Florida court, while the constitutional deficiency of the individual mandate had nothing to do with the appropriate role of Congress in federalist design of the constitution. ${ }^{279}$ Instead, the mandate was voided on syntactical grounds, supported by the premise that Congress

276. See, e.g., Second Amended Complaint, supra note 69, ๆ 86 and 88 (arguing that Medicaid reforms and health insurance mandates placed on the states deprive them of their sovereignty in dereliction of the 9 th and 10th Amendments).

277. See, e.g., id. I 60 (arguing that the individual mandate acts to confer a general police power on the federal government, which is properly reserved to the states by the 10th Amendment).

278. See, e.g., Florida ex rel Atty. Gen. v. United States Dep't. of Health \& Human Servs., 780 F. Supp. 2d 1256, 1306 (N.D. Fla. 2011) (concluding that while the Act clearly reverses traditional concepts of federalism, precedent does not allow the court to appropriately address these issues).

279. See generally id. 
may only regulate commercial "activity" under the Commerce Clause, and the decision not to purchase insurance could not properly be defined as an "activity."280 What is worse, the Eleventh Circuit Court of Appeals concluded that the individual mandate was severable from the remaining Act, leaving the most constitutionally offensive provisions in place. Under a value-based application of the anti-commandeering rule, all of these provisions would be unconstitutional because they undermine the federalist values of regulatory competition, enhancement of democracy, and prevention of tyranny. This alternative outcome would endorse the importance of such values and condemn political efforts to contravene the Constitution's textual mandates. By taking the narrower syntactical approach, the court has failed to fulfill its role in the Constitutional system and has further degraded the already decaying rule of law. However, the Supreme Court still has the opportunity to invalidate the entire Patient Protection and Affordable Care Act, and in turn strike a victory for constitutional governance. Whether the Court orients such a decision in federalist values or more specific concerns regarding the power of Congress, the outcome would serve as a step toward enforcing the Constitution's deliberate limits on federal authority. 